\title{
Spatial dynamics in physicochemistry and bacterio- and myco-plankton assemblages of Imo River in a Niger Delta community in Nigeria
}

\author{
D. H. Ogbuagu ${ }^{1 \star}$, A. A. Ayoade ${ }^{2}$ and N. B. AC-Chukwuocha ${ }^{1}$ \\ ${ }^{1}$ Department of Environmental Technology, Federal University of Technology, PMB 1526, Owerri, Nigeria. \\ ${ }^{2}$ Department of Zoology, University of Ibadan, Ibadan, Nigeria.
}

Accepted 1st March, 2011

\begin{abstract}
We investigated the spatial relationships between physicochemical variables and planktonic (bacterioand myco-plankton) assemblages of the middle reaches of the Imo River. In situ measurements and collection of water samples for laboratory analyses of physicochemical characteristics and enumeration of microbial groups were made at 7 sampling locations along the river between March 2007 and February 2008 according to standard methods. The principal components analysis was used for data reduction in the physicochemical variables, while one-way ANOVA was used to determine variance equality in means of physicochemical variables and planktonic assemblages. Post structure detection was made with means plots and relationships between the physicochemical variables and planktonic groups explored using correlation (r). Surface water temperature (SWT) varied between 24.00-28.10 (26.89 \pm 0.12$)^{\circ} \mathrm{C}$, turbidity between 11.00-279.00 (96.70 \pm 9.3$) \mathrm{NTU}$, pH between 6.00-6.70 (6.40 $\pm 0.02)$ and total dissolved solids between 19.90-38.00 (28.40 \pm 0.56$) \mathrm{mg} / \mathrm{l}$. Dissolved oxygen varied between 4.50-8.81 $(6.96 \pm 0.14) \mathrm{mg} / \mathrm{l}$, biological oxygen demand between 2.10-3.90 $(2.85 \pm 0.05) \mathrm{mg} / \mathrm{l}$, conductivity between $12.00-300.00(107.80 \pm 9.91) \mu \mathrm{S} / \mathrm{cm}$ and total hydrocarbon (THC) between $0.000-$ $0.038(0.020 \pm 0.001) \mathrm{mg} / \mathrm{l}$. Nitrate varied between $0.10-1.35(0.54 \pm 0.04) \mathrm{mg} / \mathrm{l}$, phosphate between 0.07$0.23(0.13 \pm 0.01) \mathrm{mg} / \mathrm{l}$ and sulphate between $0.90-8.10(4.35 \pm 0.25) \mathrm{mg} / \mathrm{l}$. A test of homogeneity of variance in inter-location means revealed significant inequality in both the physicochemical variables $\left[F_{(25.81)}>F_{\text {crit(3.90) }}\right]$ and planktonic groups $\left[F_{(86.16)}>F_{c r i t}(3.93)\right]$ at $P<0.05$. The $P C$ analysis revealed two major components- sulphate and nitrate, forming the extraction solution and explaining nearly $62 \%$ of the variability in the original 12 variables. PC 2 correlated negatively with $H U F(r=-0.687)$ at $P<0.01$, even as conductivity correlated negatively with HUF $(r=-0.555)$, and THC with THB $(r=-0.635)$, THF $(r=-0.642)$ and HUB $(r=-0.596)$ at $P<0.05$. Seven HUB genera (Bacillus sp., Arthrobacter sp., Corynebacter sp., Pseudomonas sp., Escherichia coli, Micrococcus sp. and Serratia sp.) and 4 HUF genera (Rhizopus sp., Cladosporium sp., Aspergillus sp. and Mucor sp.) were identified across the sampling locations. Though its comparatively low levels in this study could infer biogenic origin in a hydrocarbon rich region, the contributory significant correlational effect, as well as spatial variation in THC most probably determined planktonic assemblages abundance in the sampling locations.
\end{abstract}

Key words: Bacterioplankton, spatial variation, biogenic inputs, hydrocarbon utilizing fungi, physicochemistry.

\section{INTRODUCTION}

Many groups of organisms (including algae, macrophytes, protozoans and fish) have been used as bioindicators in aquatic ecosystems. Microorganisms such as bacteria, fungi and virus have also been used in

\footnotetext{
*Corresponding author. E-mail: henrydike2002@yahoo.com.
}

water quality monitoring (APHA, 1998). Plankton (all those mixed group of tiny living plants and animals that float, drift freely or feebly swim in water column, independent of the shores and bottom) have been extensively used in the establishment of water quality status. These groups of organism play a major role in the biogeochemical cycles of many important elements (such as the carbon cycle, nitrification, denitrification, 
reminerilization, and methanogenesis) and occupy the base level of food chains that lead up to commercially important fisheries. Spaak and Bauchrowitz (2010) classified plankton into phytoplankton (autotrophic pro- or eukaryotic algae that live in the euphotic zones of water), zooplankton (small protozoans or metazoans that feed on other plankton, or even some eggs and larvae of fish, crustaceans, and annelids), bacterioplankton (bacteria and archaea, which play important role in remineralization of organic matter down the water column) and mycoplankton (fungi; achlorophyllous heterotrophic microscopic plants that also contribute to remineralization in water column).

Of the various approaches used in water quality monitoring, the use of biological indicators in conjunction with physicochemical characteristics has been advocated as a fundamental prerequisite for the establishment of ecological baseline as well as environmental changes in freshwater bodies (Cairns and van der Schalie, 1980).

Being aquatic organisms, environmental factors associated with habitat pollution could have profound effects on plankton community composition and abundance (Armitage and Blackburn, 1985; Boyd, 2000; Havas and Hutchinson, 1982; Yamamoto, 1986; Egborge, 1994; Aoyagui and Bonecker, 2004; Okogwu and Ugwumba, 2006). For example, Aas et al. (1996) identified solar UV radiation, virus, and heterotrophic flagellates as some limiting factors to bacterioplankton abundance. Already, Karantz et al. (1994) and GarciaPichel (1994) had observed that this could be due to their lack of UV screening pigments. Bacterioplankton and mycoplankton occupy a range of ecological niches in aquatic ecosystems. For example, many bacterioplankton species are autotrophic - deriving energy from either photosynthesis or chemosynthesis, while the mycoplankton are saprophytic and so contribute to reminerilization in water columns. Like other plankton, bacterioplankton and mycoplankton are preyed upon by zooplankton and so, occupy the centre of food web (Pomeroy and Wiiebe, 1998), having similar function to phytoplankton and protists

Although these plankton groups are mostly either autotrophic or heterotrophic, a shadowy taxonomical distinction in members has resulted in classifying some as mixotrophic (Newell and Newell, 1963). This characteristic thus informs their identifications based on heterotrophy and utilization of either a wide range of substrates or a narrow one such as hydrocarbonoclastic utilization, especially in a hydrocarbon-rich environment such as the present one.

Several plankton studies in the Niger Delta of Nigeria limited their scopes to the phytoplankton and zooplankton groups, thus according little or no attention to the bacterio- and myco-plankton categories. Worse still, the few plankton studies on the Imo River (one of the major inland freshwaters of the Niger Delta region of Nigeria) were for surveillance uses only, and so were not comprehensive. Yet, this river traverses the hub of hydrocarbon deposit in this region, which associated industrial pollution inputs could perturb the aquatic quality regime. In this research therefore, we attempted to close this gap, utilizing a spatial approach to capture trends with the following objectives:

1) Determination of spatial variation in physicochemical characteristics.

2) Determination of spatial variation in bacterioplankton and mycoplankton abundance and diversity.

3) Determination of the interrelationships existing between the physicochemical variables and planktonic groups.

\section{MATERIALS AND METHODS}

\section{Study area}

Etche in Rivers State, Nigeria is located between longitudes $06^{\circ} 05^{\prime}$ and $07^{\circ} 14^{\prime} \mathrm{N}$ and latitudes $05^{\circ} 08^{\prime}$ and $04^{\circ} 45^{\prime} \mathrm{E}$. It has a climate typical of the tropical rainforest. Annual rainfall is about $2500 \mathrm{~mm}$, with wet season usually lasting for 9 months (March-November) and short dry season for the rest of the year. Temperature is between 24 and $38^{\circ} \mathrm{C}$ and relative humidities of up to $90 \%$ are recorded during the wet season. One of her main water systems is the Imo River; a freshwater that rises from Okigwe/Awka uplands in the neighbouring eastern Imo State and runs across the area, onto Oyigbo, Khana, Opobo/Nkoro, and Andoni LGAs in Rivers State, and then empties independently into the Atlantic Ocean. In ELGA, the river is at its middle course, alluvial, and experiences flooding usually at the peak of the wet season between August and November yearly.

\section{Sampling stations}

Seven sampling locations were designated along the course of the river in the LGA (Figure 1.). Sampling location 1 (the reference location) was located at Akwa community, while locations 2, 3, and 4 were located at Odagwa and 5, 6, and 7 at Umuebulu community at intervals of about $500 \mathrm{~m}$ in each community. However, locations 2 and 5 were about $2 \mathrm{~km}$ from 1 and 4 respectively. Table 1 shows the GPS coordinates of the sampling locations.

\section{Physicochemical analysis}

Sampling for physicochemical parameters was conducted monthly from March 2007 to February 2008 in the afternoon hours. Surface water temperature (SWT), conductivity, $\mathrm{pH}$, turbidity and dissolved oxygen were measured in situ with a HORIBA U-10 Water Quality Checker that had been standardized. Biological oxygen demand (BOD) was determined after 5 days incubation period at $20 \pm 1^{\circ} \mathrm{C}$ with same HORIBA U-10 Water Quality Checker, while total dissolved solids (TDS), alkalinity, nitrate, phosphate, sulphate and total hydrocarbon (THC) were determined according to APHA (1998).

\section{Microbiological analysis}

Water samples were collected in replicates with sterile Nickson Water Sampler at each of the sampling locations monthly from the pelagial and deeper columns and composited. Total heterotrophic 


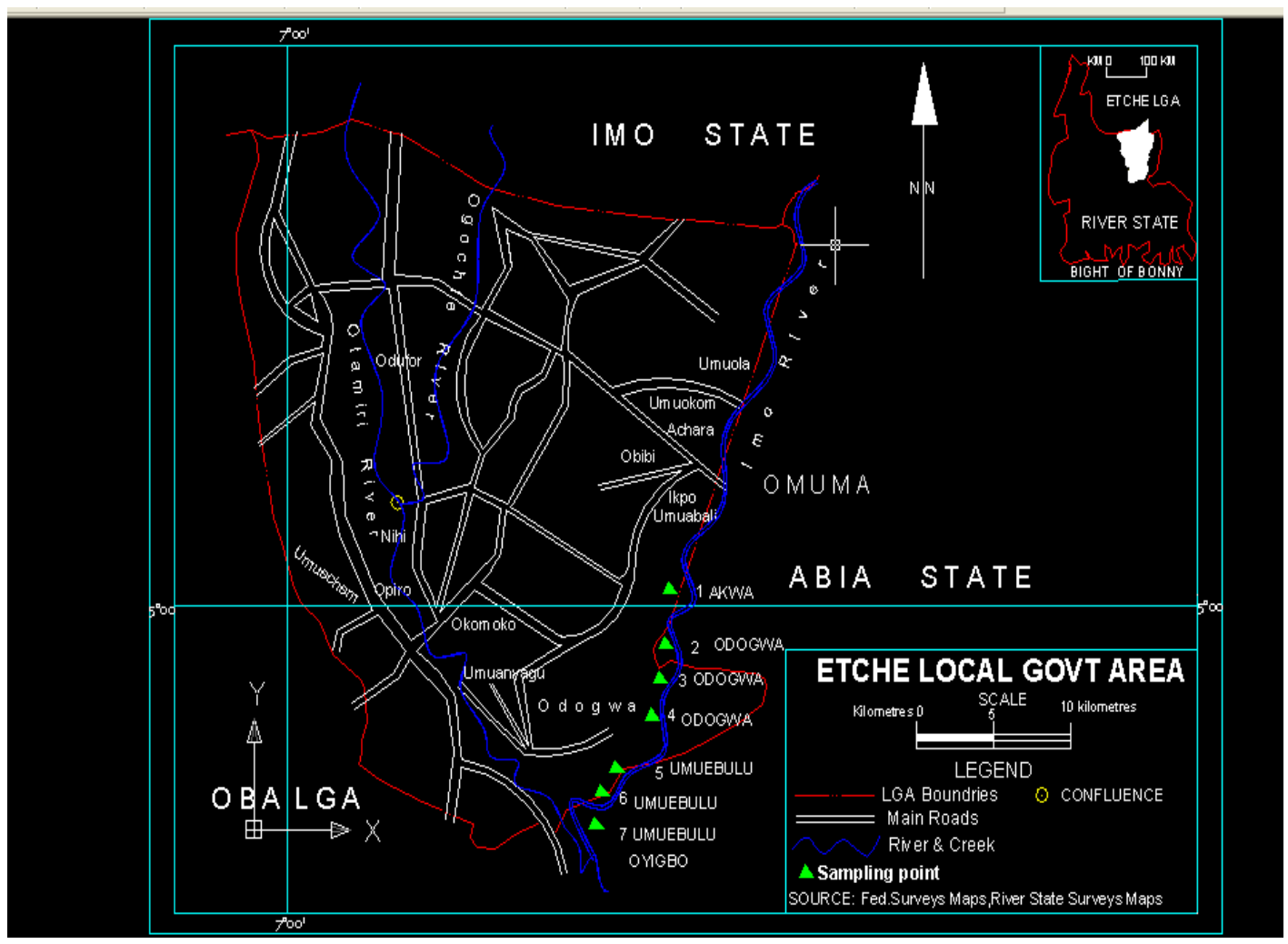

Figure 1. Map of Etche Local Government Area showing the sampling locations.

Table 1. GPS coordinates of the sampling locations along Imo River in ELGA.

\begin{tabular}{lccccccc}
\hline \multirow{2}{*}{ GPS parameter } & \multicolumn{7}{c}{ Sampling locations } \\
\cline { 2 - 7 } & $\mathbf{1}$ & $\mathbf{2}$ & $\mathbf{3}$ & $\mathbf{4}$ & $\mathbf{5}$ & $\mathbf{6}$ \\
\hline Northing & $05^{\circ} 01.042^{\prime}$ & $04^{\circ} 58.860^{\prime}$ & $04^{\circ} 58.169^{\prime}$ & $04^{\circ} 58.667^{\prime}$ & $04^{\circ} 53.391^{\prime}$ & $04^{\circ} 53.631^{\prime}$ & $04^{\circ} 54.218^{\prime}$ \\
Easting & $007^{\circ} 10.212^{\prime}$ & $007^{\circ} 10.274^{\prime}$ & $007^{\circ} 09.663^{\prime}$ & $007^{\circ} 10.055^{\prime}$ & $007^{\circ} 08.573^{\prime}$ & $007^{\circ} 08.681^{\prime}$ & $007^{\circ} 08.541^{\prime}$ \\
Elevation (m) & 20.9 & 14.3 & 18.5 & 24.5 & 3.0 & 5.3 & 9.4 \\
Accuracy $(\mathrm{m})$ & 21.8 & 11.3 & 21.7 & 7.6 & 54.2 & 8.5 & 21.1 \\
\hline
\end{tabular}

GPS = Global positioning system.

bacteria (THB) were enumerated with nutrient agar (NA) (Oxoid) while total heterotrophic fungi (THF) were enumerated with potato dextrose agar (PDA). The modified mineral salt agar (MS) was used to isolate the hydrocarbon utilizing fungi (HUF) while the unmodified MS agar was used to isolate the hydrocarbon utilizing bacteria (HUB) applying the vapour phase transfer method of Thijsse and van der Linden (1961) as modified by Okpokwasili and Amanchukwu (1988). Biochemical characterization and identification of the HUB and HUF were conducted using keys provided in the Bergey's Manual of Determinative Bacteriology (1993) and Mills et al. (1978), respectively.

\section{Statistical analysis}

The SPSS Version 17.0 and MS Excel softwares were used in the analysis of ensuing data. The factor analysis, utilizing the principal components analysis (PCA) extraction for data reduction was used to reduce redundant physicochemical variables from the data file and replacing the entire data file with a smaller number of uncorrelated factor and to further examine the latent relationships between the variables. Factor rotation was achieved with varimax method and the magnitudes of the eigenvalues and $75 \%(0.75)$ rule for variance contribution were used for factor selection. The oneway analysis of variance (ANOVA) was used to determine variance equality in means of the physicochemical variables as well as plankton abundances spatially, while post structure detection was made with means plots. The influence of the physicochemical variables on plankton assemblages was determined with the Pearson product moment correlation coefficient (r).

\section{RESULTS}

\section{Spatial variation in physicochemical characteristics}

Surface water temperature (SWT), $\mathrm{pH}$, and total alkalinity 


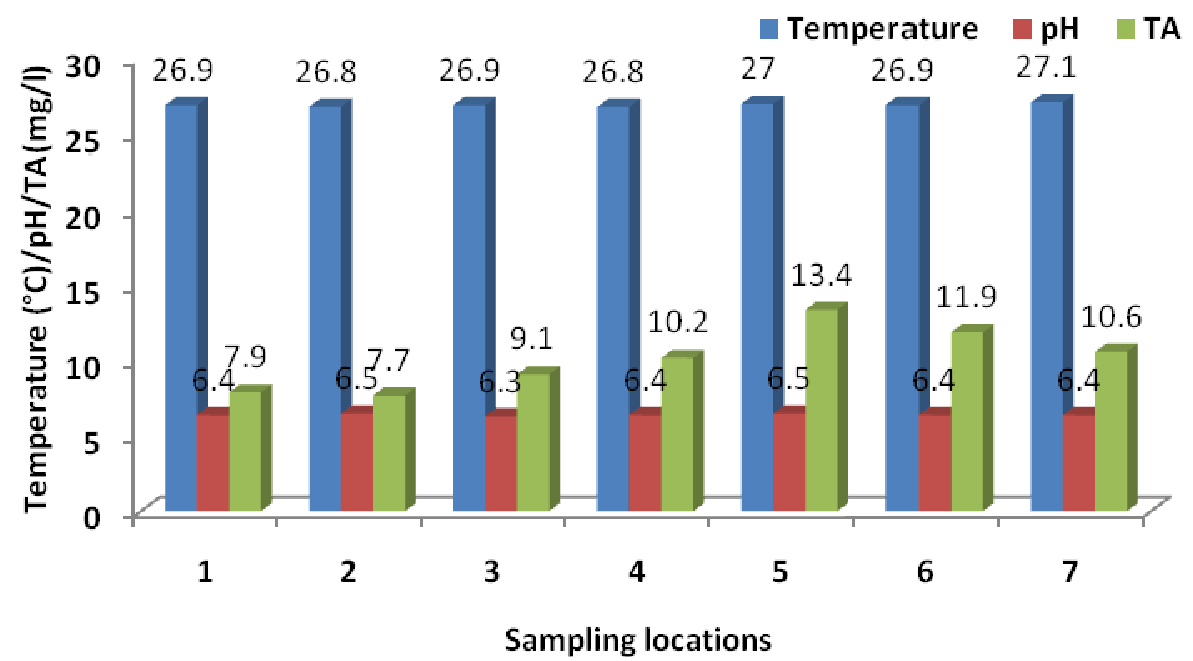

Figure 2. Spatial variation in mean temperature, $\mathrm{Ph}$ and total alkalinity of Imo River in ELGA.

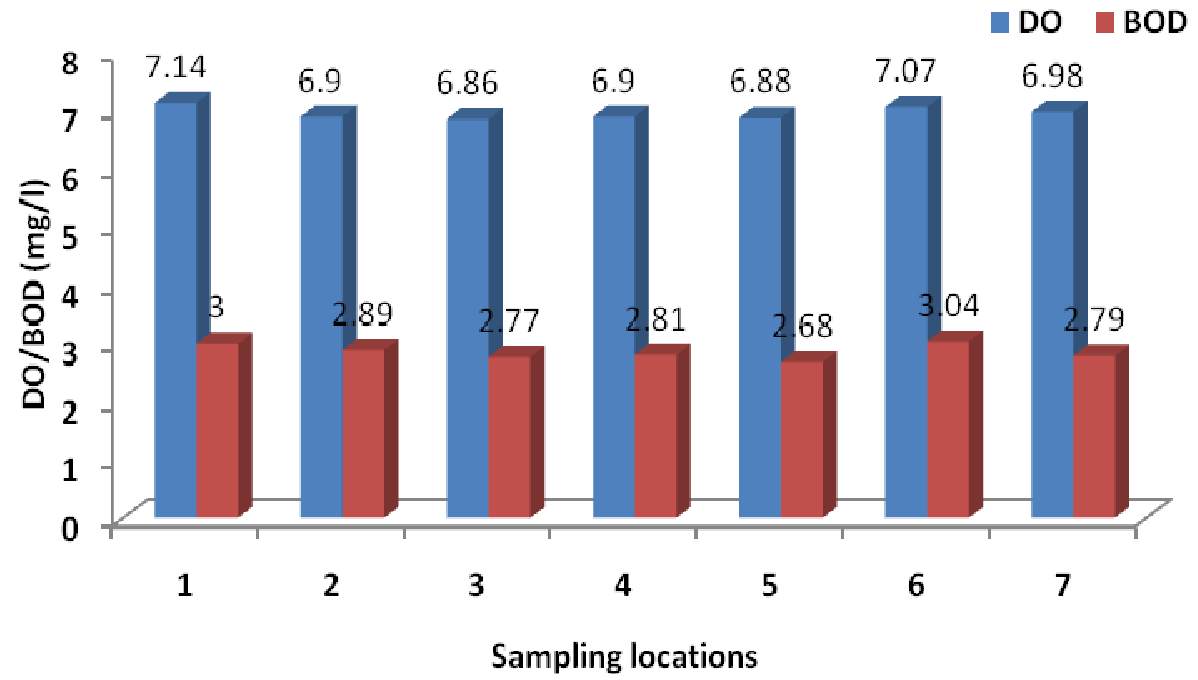

Figure 3. Spatial variation in mean dissolved oxygen and biological oxygen demand of Imo River in ELGA.

(TA) ranged from $24.00-28.10(26.89 \pm 0.12)^{\circ} \mathrm{C}, 6.00-$ $6.70(6.40 \pm 0.02)$, and $1.50-20.00(10.10 \pm 0.44) \mathrm{mg} / \mathrm{l}$ respectively across the sampling locations. Highest SWT $\left(27.1^{\circ} \mathrm{C}\right), \mathrm{pH}(6.5)$, and $\mathrm{TA}(13.4 \mathrm{mg} / \mathrm{l})$ were recorded in sampling locations 7, 2 and 5, and 5, respectively (Figure 2). However, least values of $26.8^{\circ} \mathrm{C}, 6.3$, and $7.7 \mathrm{mg} / \mathrm{l}$ were recorded in locations 2 and 4,3 , and 2 , respectively.

Dissolved oxygen (DO) and biological oxygen demand (BOD) varied from 4.50-8.81 (6.96 \pm 0.14$)$ and 2.10-3.90 $(2.85 \pm 0.05) \mathrm{mg} / \mathrm{l}$, respectively. Highest values (7.14 and $3.04 \mathrm{mg} / \mathrm{l})$ were recorded in locations 1 and 6 , while least values $(6.86$ and $2.68 \mathrm{mg} / \mathrm{l})$ were recorded in locations 3 and 5 , respectively (Figure 3 ).
Turbidity ranged from 11.00-279.00 $(96.70 \pm 9.31)$ NTU, total dissolved solids (TDS) ranged from 19.90-38.00 $(28.41 \pm 0.56) \mathrm{mg} / \mathrm{l}$, while conductivity ranged from 12.00 $300.00 \quad(107.80 \pm 9.91) \mu \mathrm{S} / \mathrm{cm}$ across the sampling locations. Highest turbidity (104.3 NTU), TDS (29.9 mg/l), and conductivity $(120.5 \mu \mathrm{S} / \mathrm{cm})$ were recorded in sampling locations 2,3 , and 3 , respectively (Figure 4). However, least values of the variables (85.5 NTU, 27.0 $\mathrm{mg} / \mathrm{l}$, and $92.0 \mu \mathrm{S} / \mathrm{cm}$ ) were recorded in locations 1,6 , and 1 , respectively.

Nitrate, phosphate, and sulphate varied between 0.10 1.35 (0.54 \pm 0.04$), 0.07-0.23(0.13 \pm 0.01)$, and 0.90-8.10 $(4.35 \pm 0.25) \mathrm{mg} / \mathrm{l}$, respectively; with highest values of $0.59,0.15$, and $4.80 \mathrm{mg} / \mathrm{l}$ recorded in sampling locations 


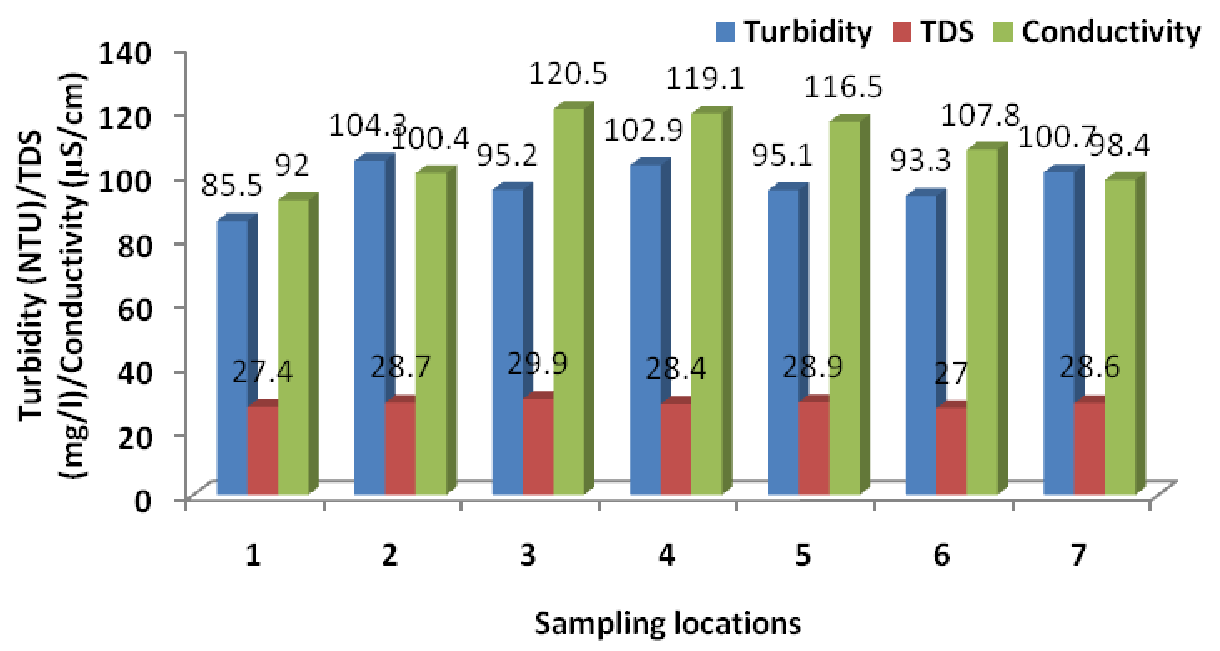

Figure 4. Spatial variation in mean turbidity, total dissolved solids and conductivity of Imo River in ELGA.

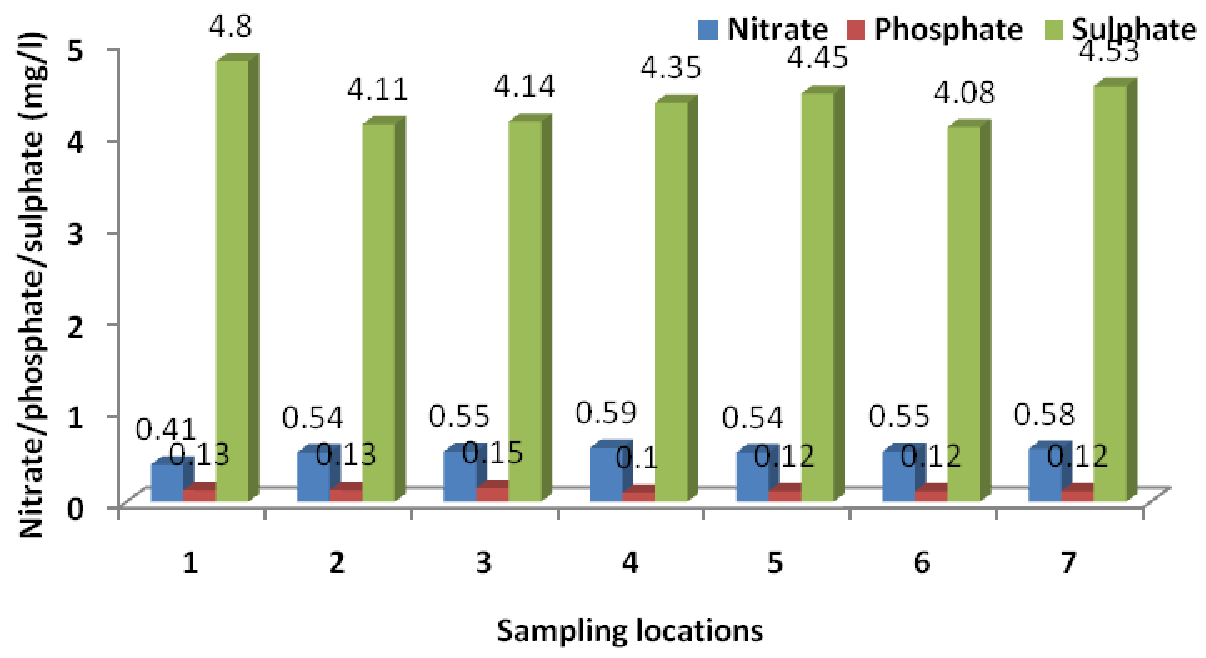

Figure 5. Spatial variation in mean nutrients of Imo River in ELGA.

4,3 , and 1 , and least values of $0.41,0.10$, and $4.08 \mathrm{mg} / \mathrm{l}$ recorded in locations 1,4 , and 6 , respectively (Figure 5).

However, total petroleum hydrocarbons (THC) ranged between 0.000-0.038 (0.020 \pm 0.001$) \mathrm{mg} / \mathrm{l}$, with maximum value of $0.024 \mathrm{mg} / \mathrm{l}$ recorded in locations 4 and 7 , and least value of $0.007 \mathrm{mg} / \mathrm{l}$ recorded in location 1 (Figure 6).

A test of homogeneity of variance in means between sampling locations using the one-way analysis of variance (ANOVA) revealed significant inequality in both the physicochemical variables $\left[F_{(25.81)}>F_{\text {crit(3.90) }}\right]$ and plankton groups $\left[F_{(86.16)}>F_{c r i t}(3.93)\right]$ at $P<0.05$. A further structure detection using the post-ANOVA means plots and TA as factor variable revealed that for the physicochemical variables, the inequalities were mostly observed between sampling locations 2 and 1 (except in phosphates), 3 and 4, 4 and 7(except in $\mathrm{pH}$ and THC), 7 and 6 (except in $\mathrm{pH}$ and phosphate), 6 and 5 (except in phosphate), and 1 and 3 (except in SWT) (Figure 7a-k). With the HUB as factor variable, the inequalities in plankton groups were revealed to occur mostly between sampling locations 1 and 2, 4 and 6, and 2 and 5 (except in HUF) (Figure 8a-c).

\section{Principal component analysis}

The first two principal components (PCs) formed the extraction solution, as the extracted components explained nearly $62 \%$ of the variability in the original 12 




Fig. 1.6. Spatial variation in mean total petroleum hydrocarbon of Imo River in ELGA

Figure 6. Spatial variation in mean total petroleum hydrocarbon of Imo River in ELGA.

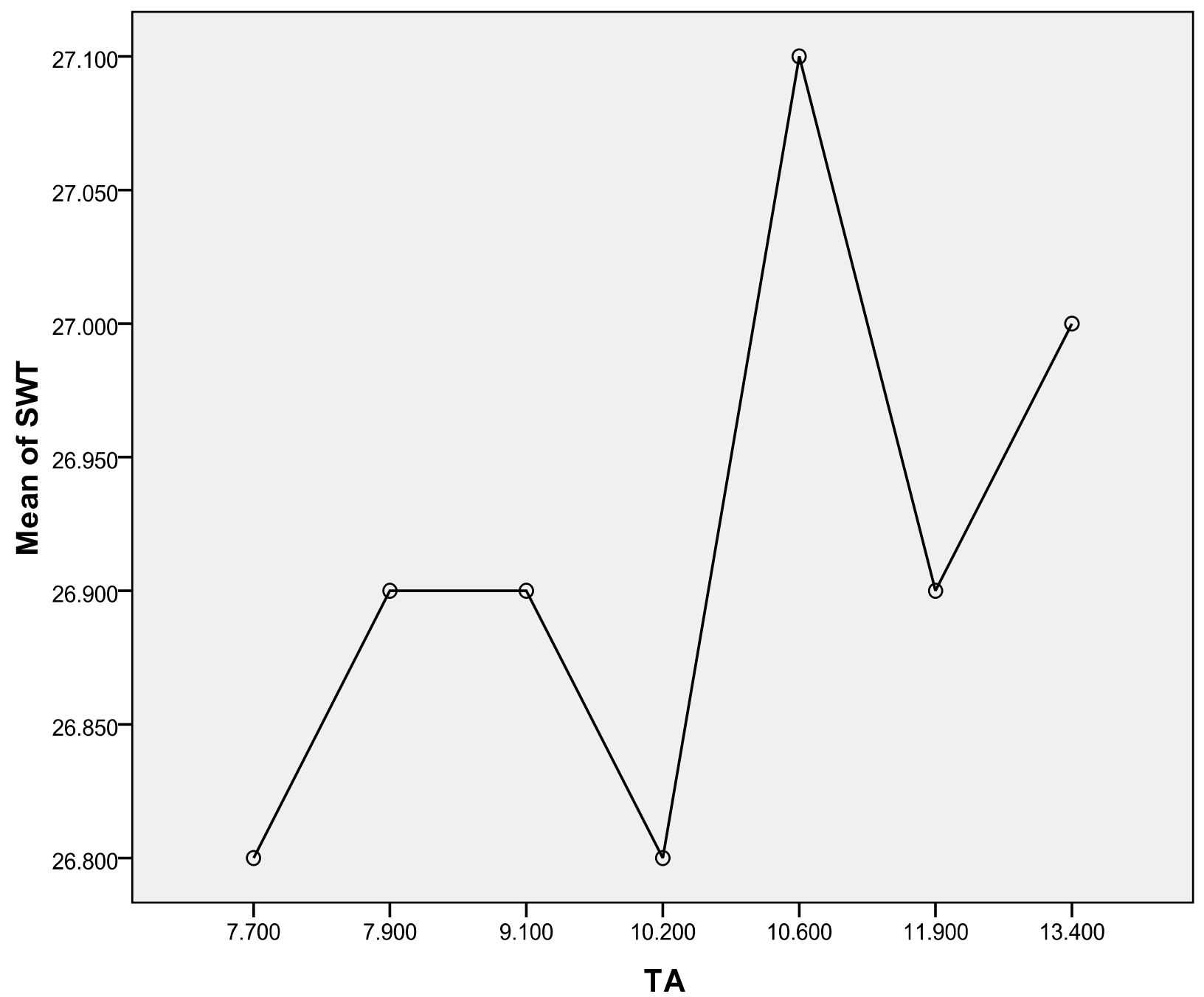

Figure 7a. Structure detection between SWT and TA using means plot. 


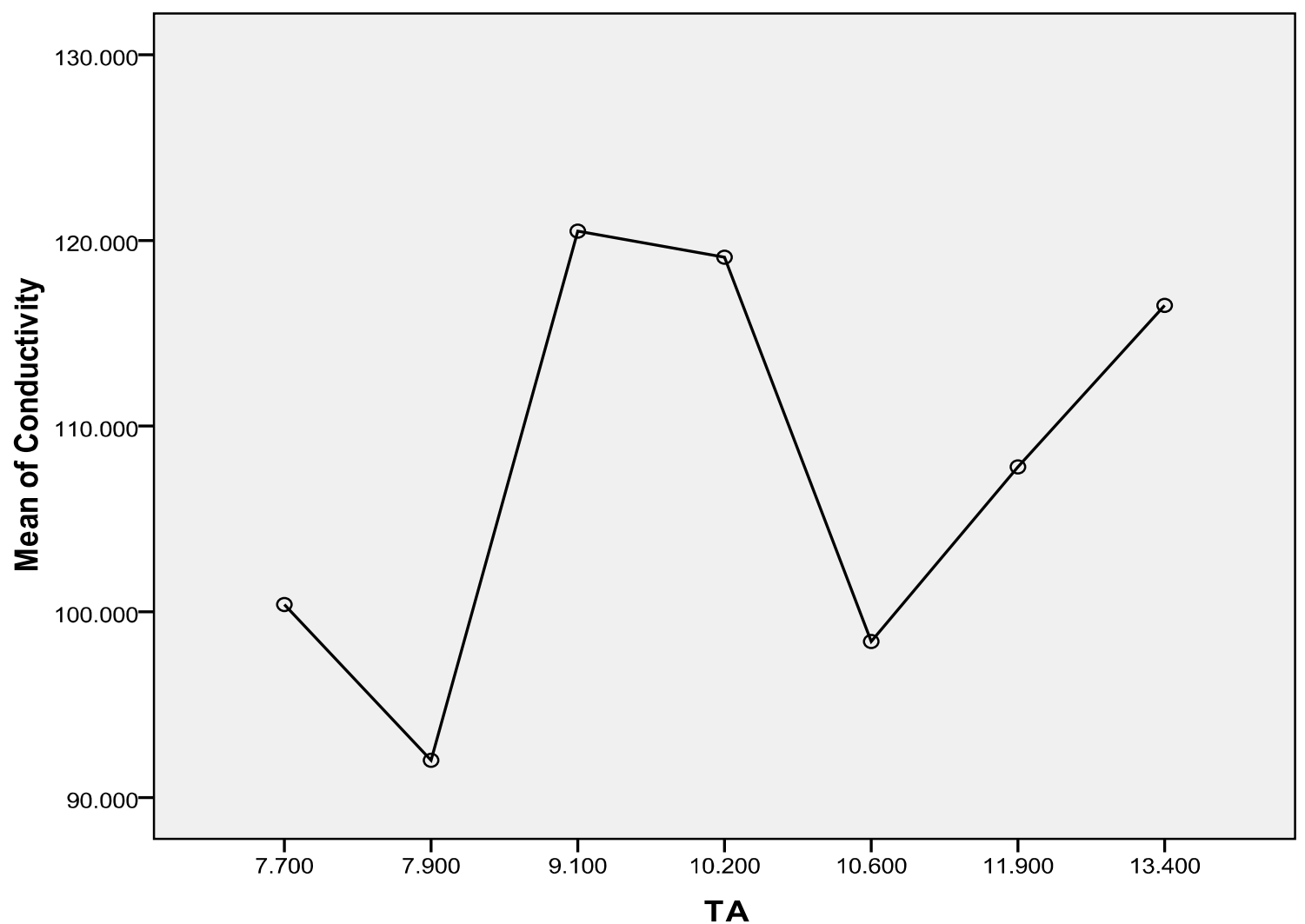

Figure 7b. Structure detection between conductivity and TA using means plot.

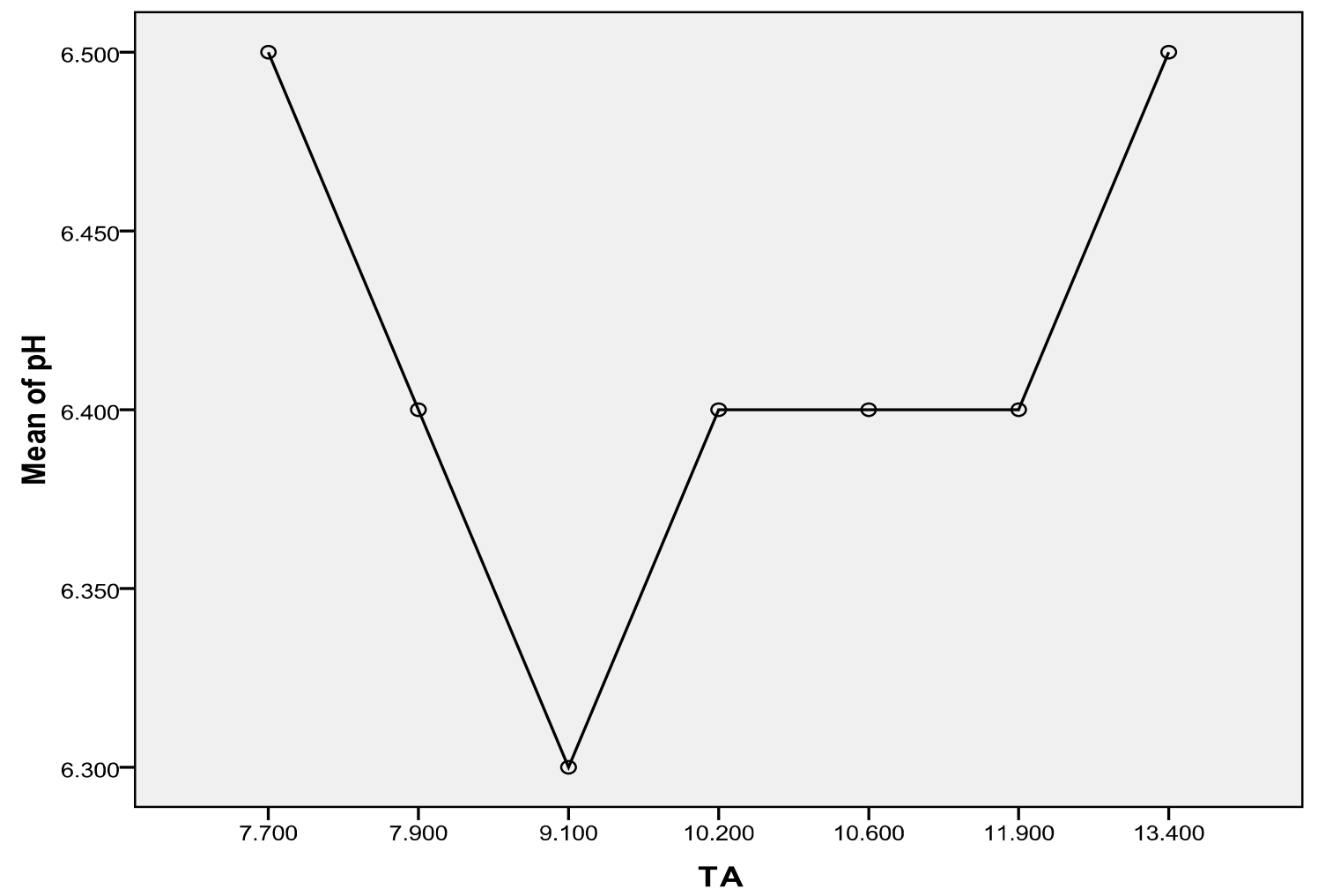

Figure 7c. Structure detection between $\mathrm{pH}$ and TA using means plot. 


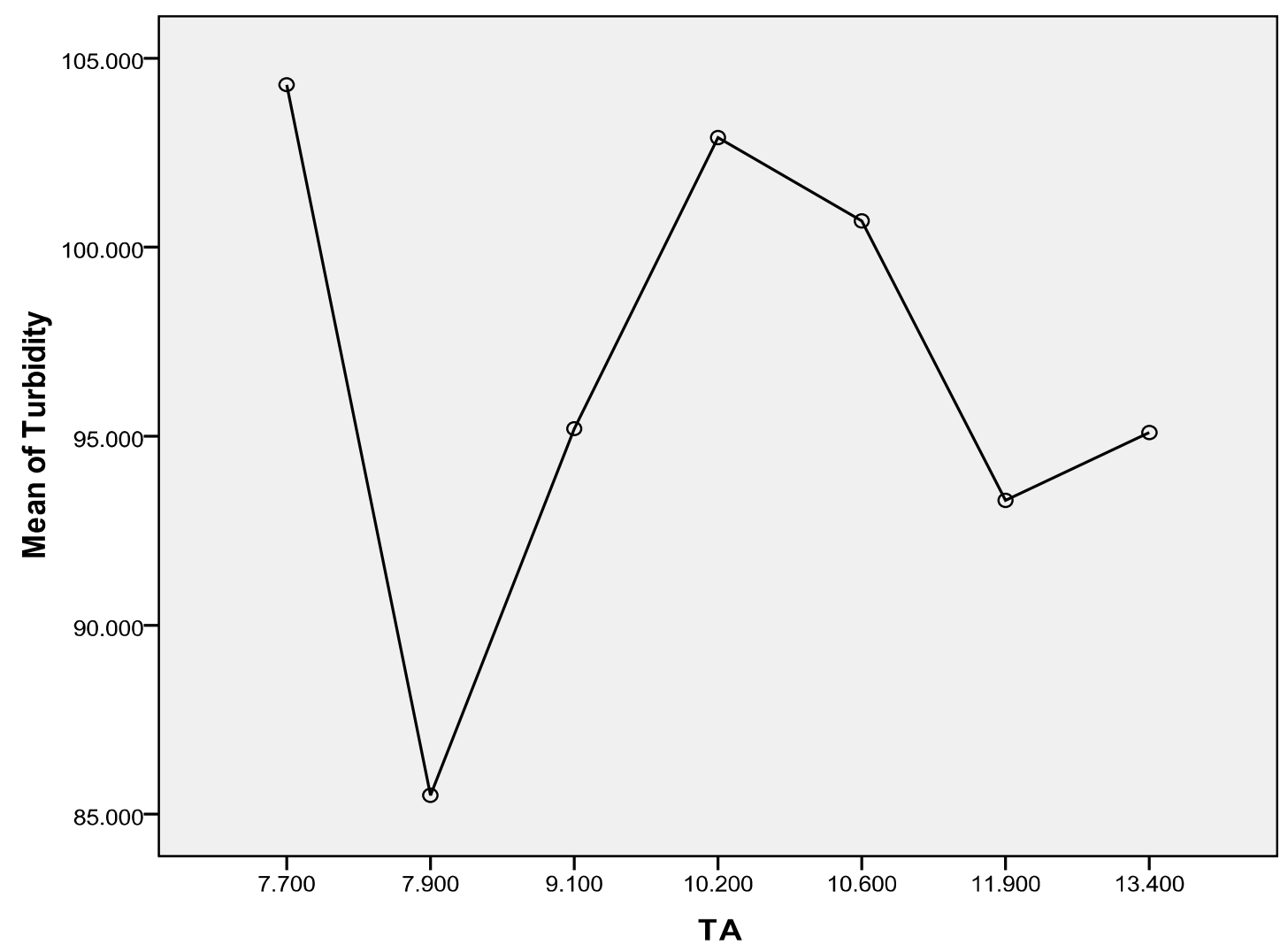

Figure 7d. Structure detection between turbidity and TA using means plot.

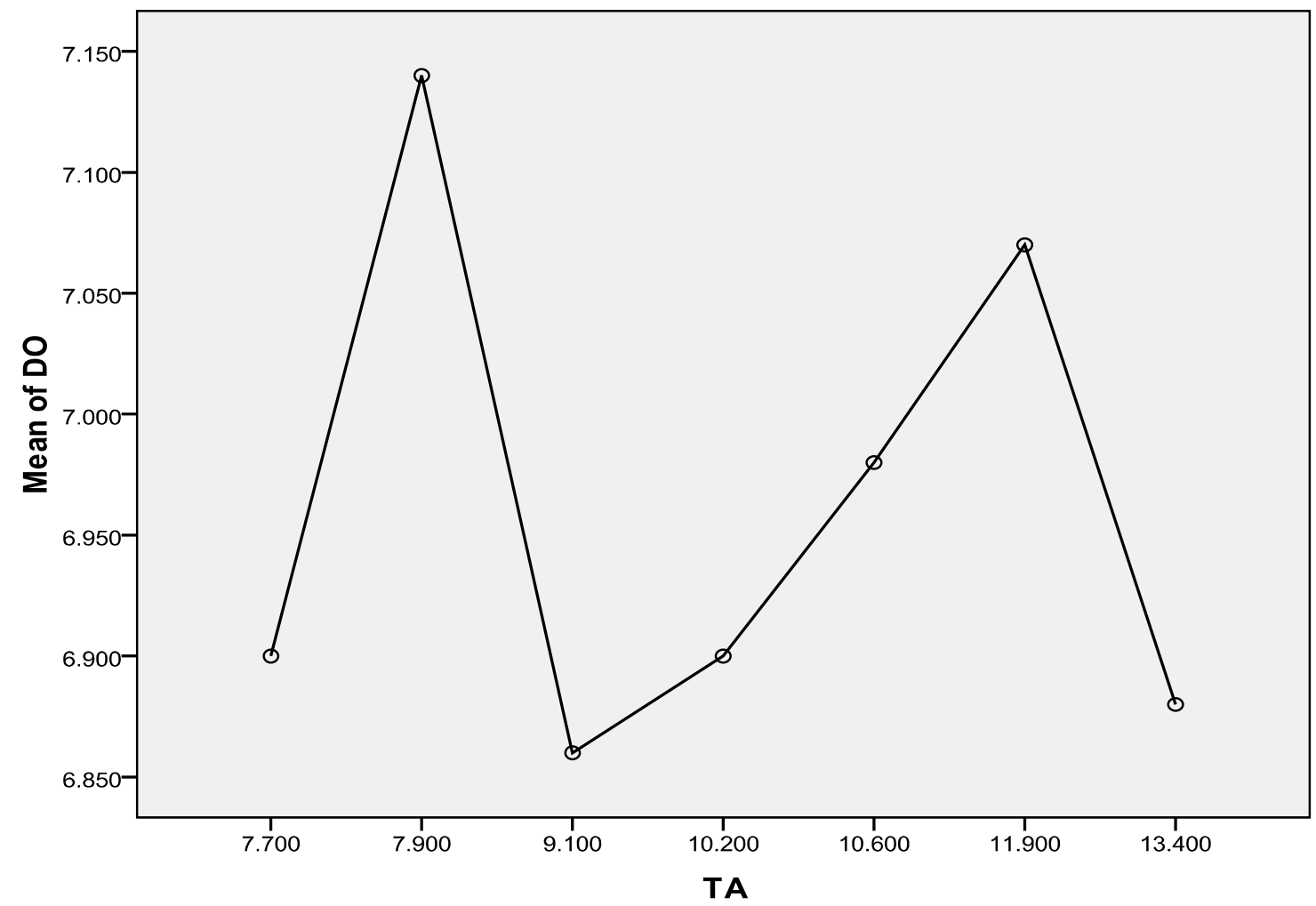

Figure 7e. Structure detection between DO and TA using means plot. 


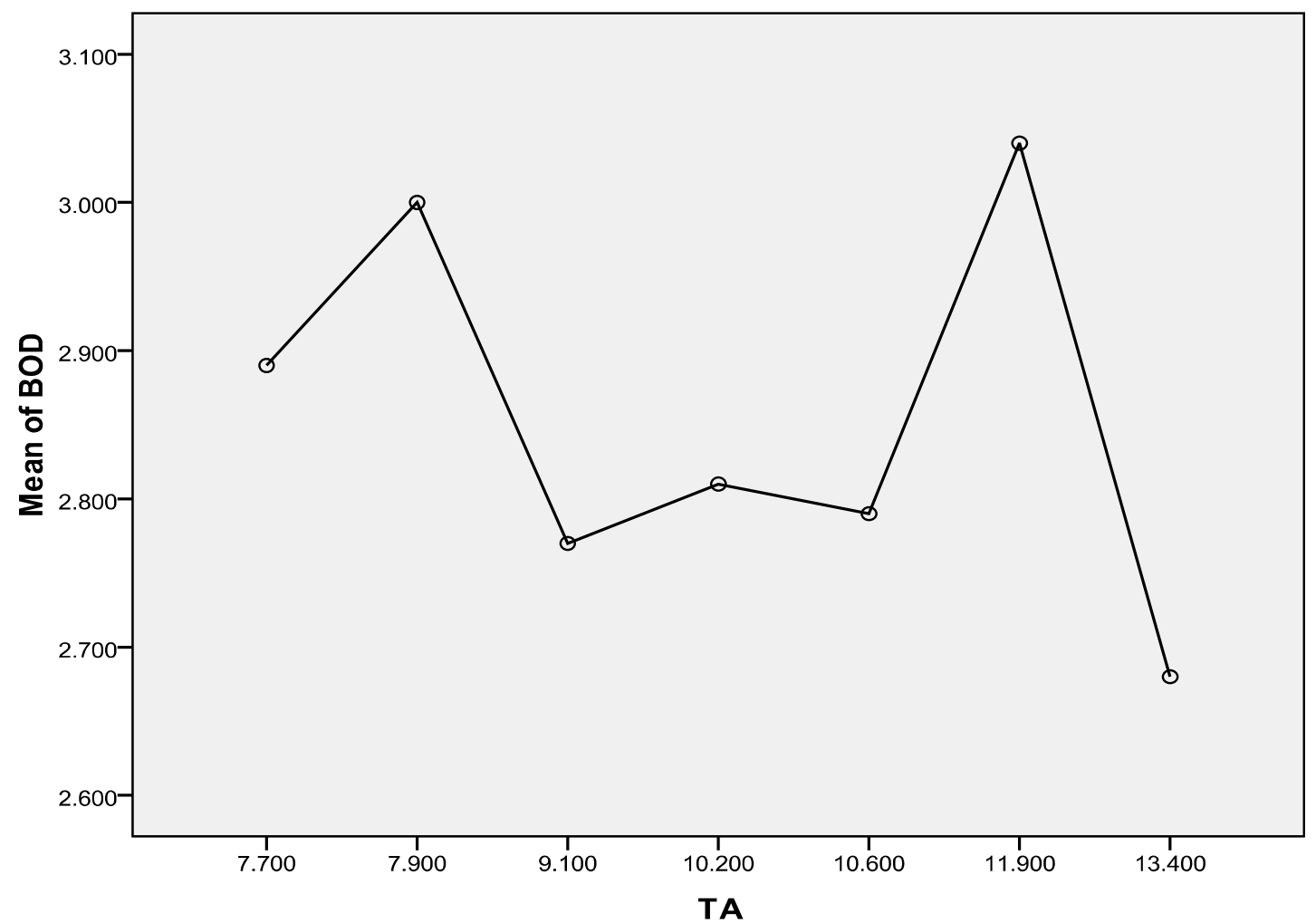

Figure 7f. Structure detection between BOD and TA using means plot.

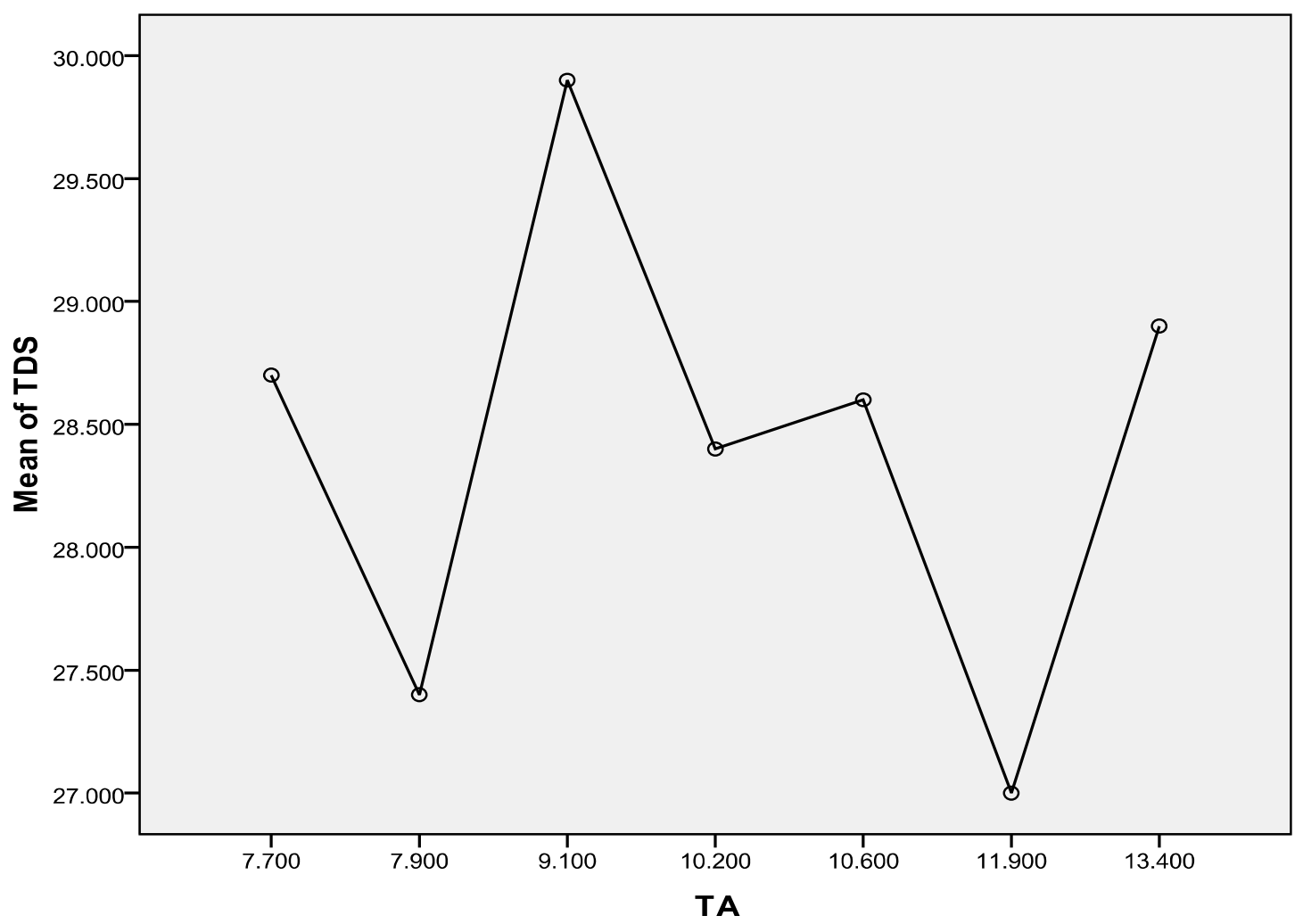

Figure 7g. Structure detection between TDS and TA using means plot. 


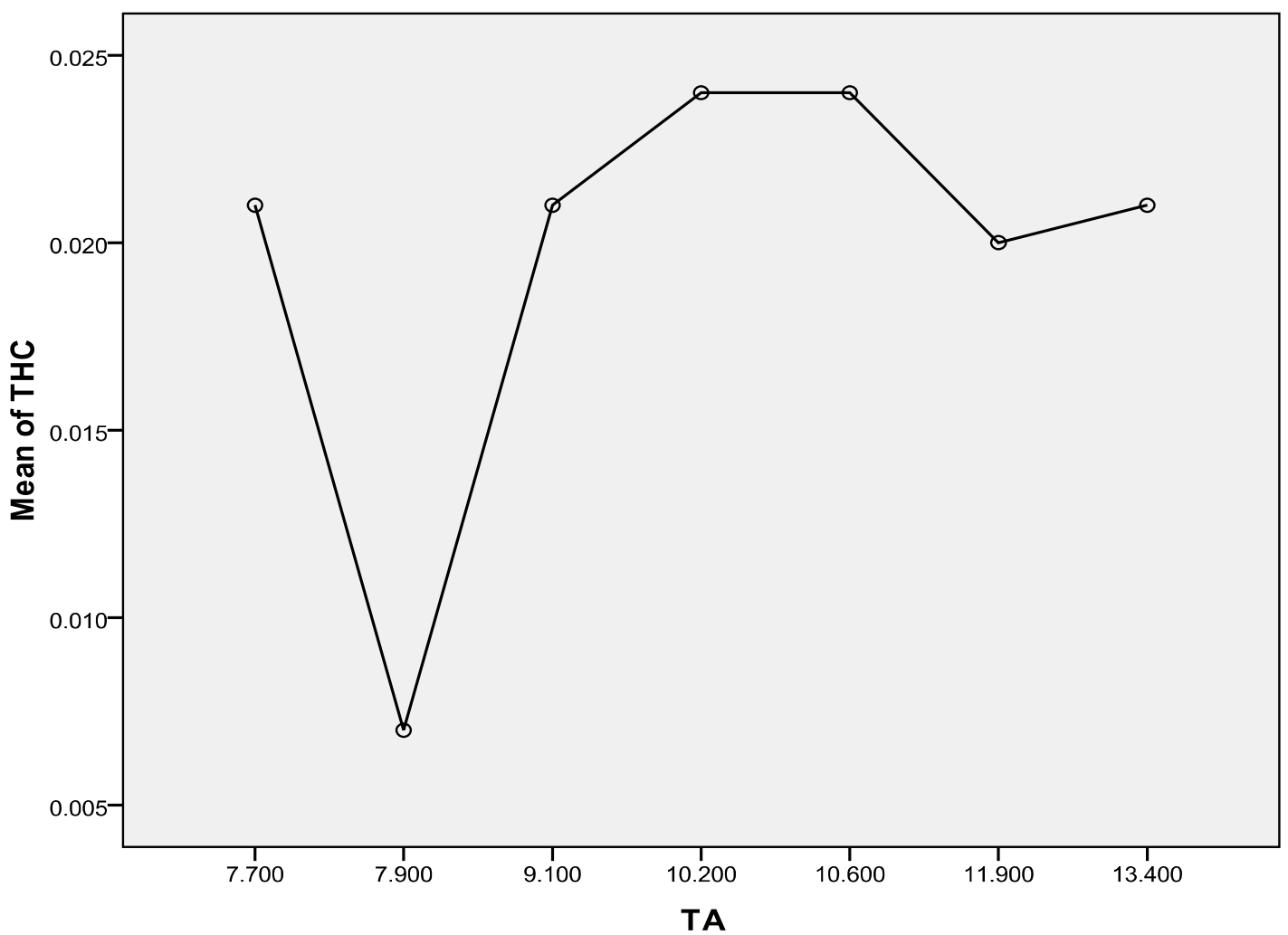

Figure 7 h. Structure detection between THC and TA using means plot.

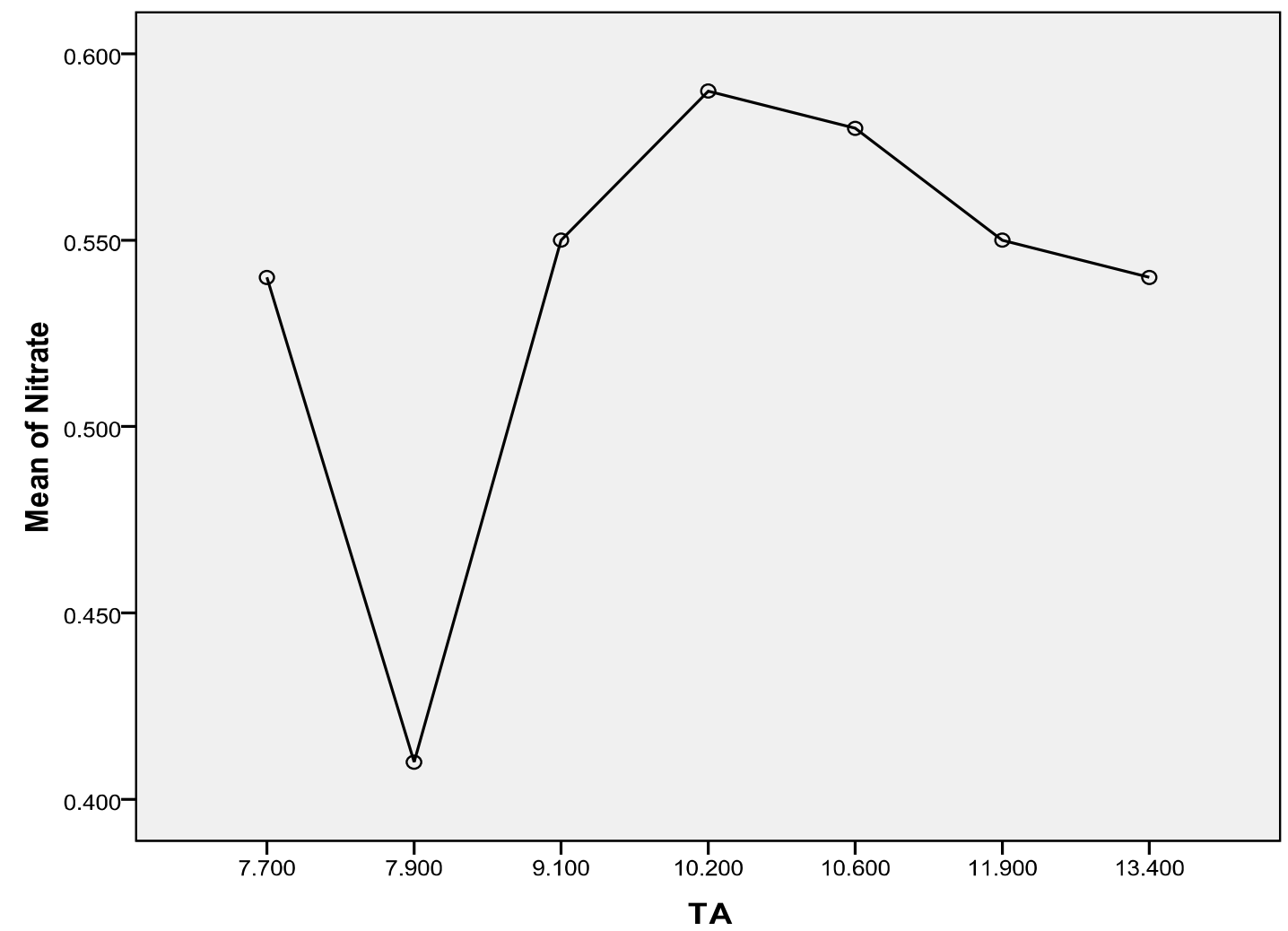

Figure 7i. Structure detection between nitrate and TA using means plot. 


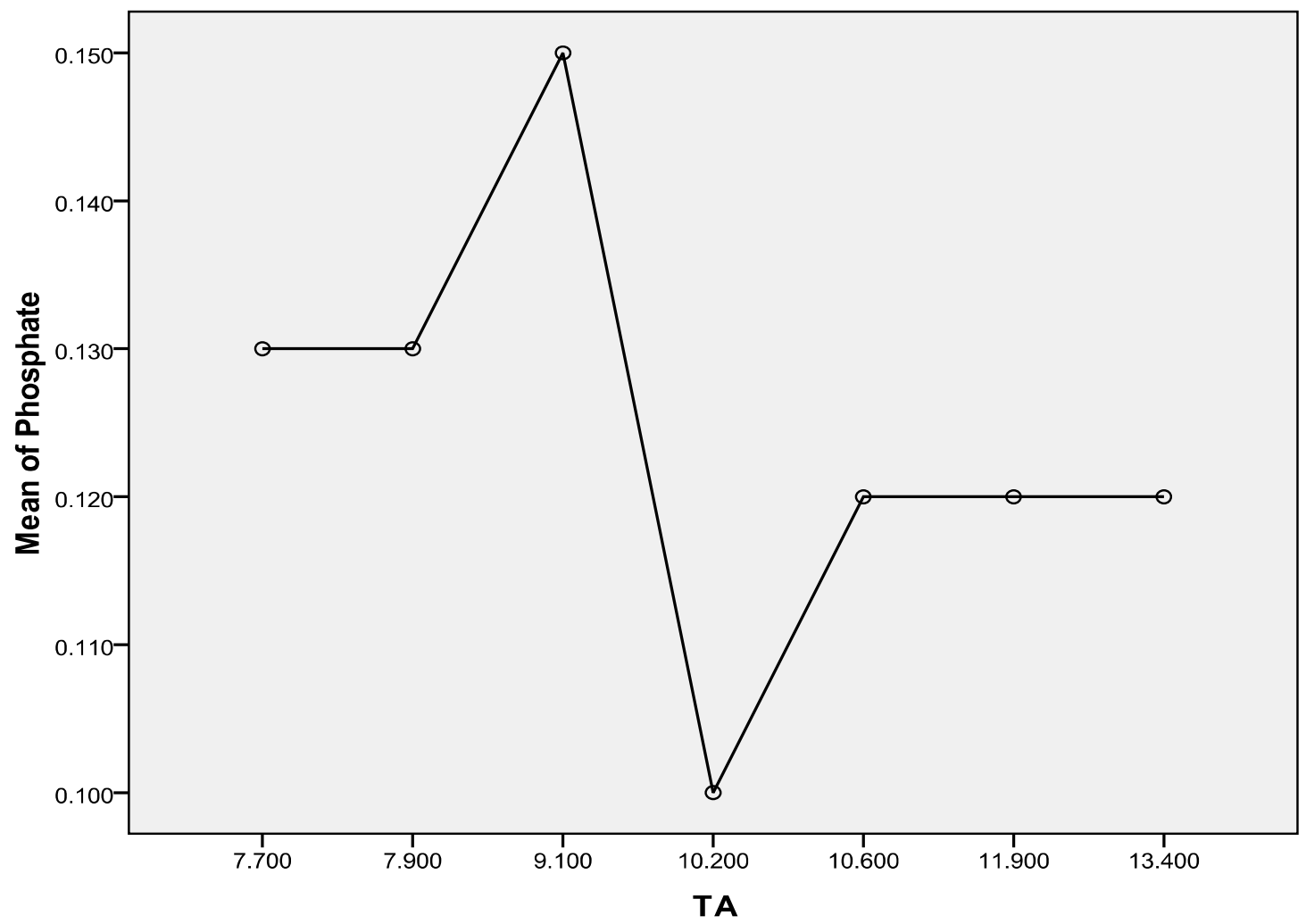

Figure 7j. Structure detection between phosphate and TA using means plot.

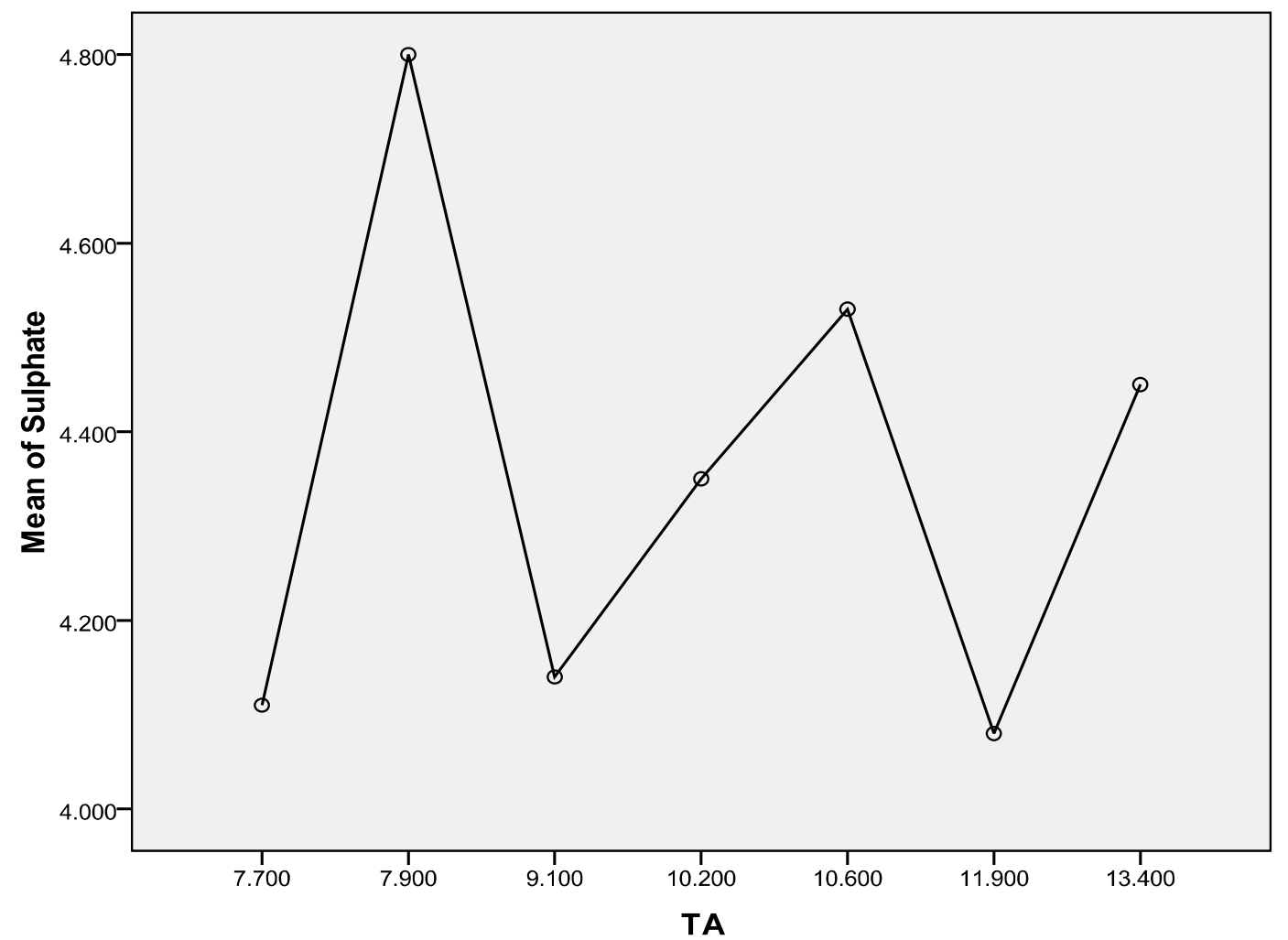

Figure 7k. Structure detection between sulphate and TA using means plot. 


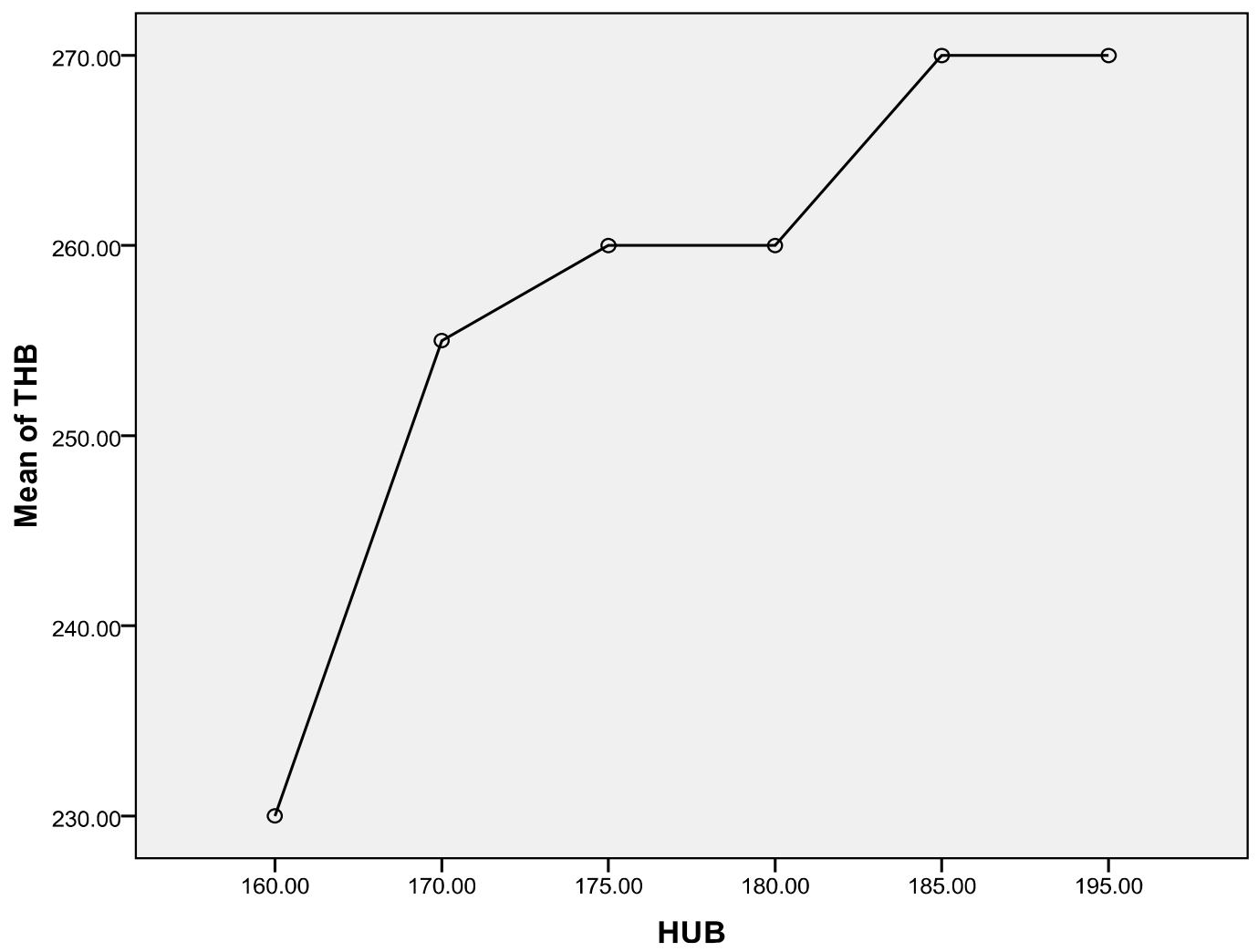

Figure 8a. Structure detection between THB and HUB using means plot.

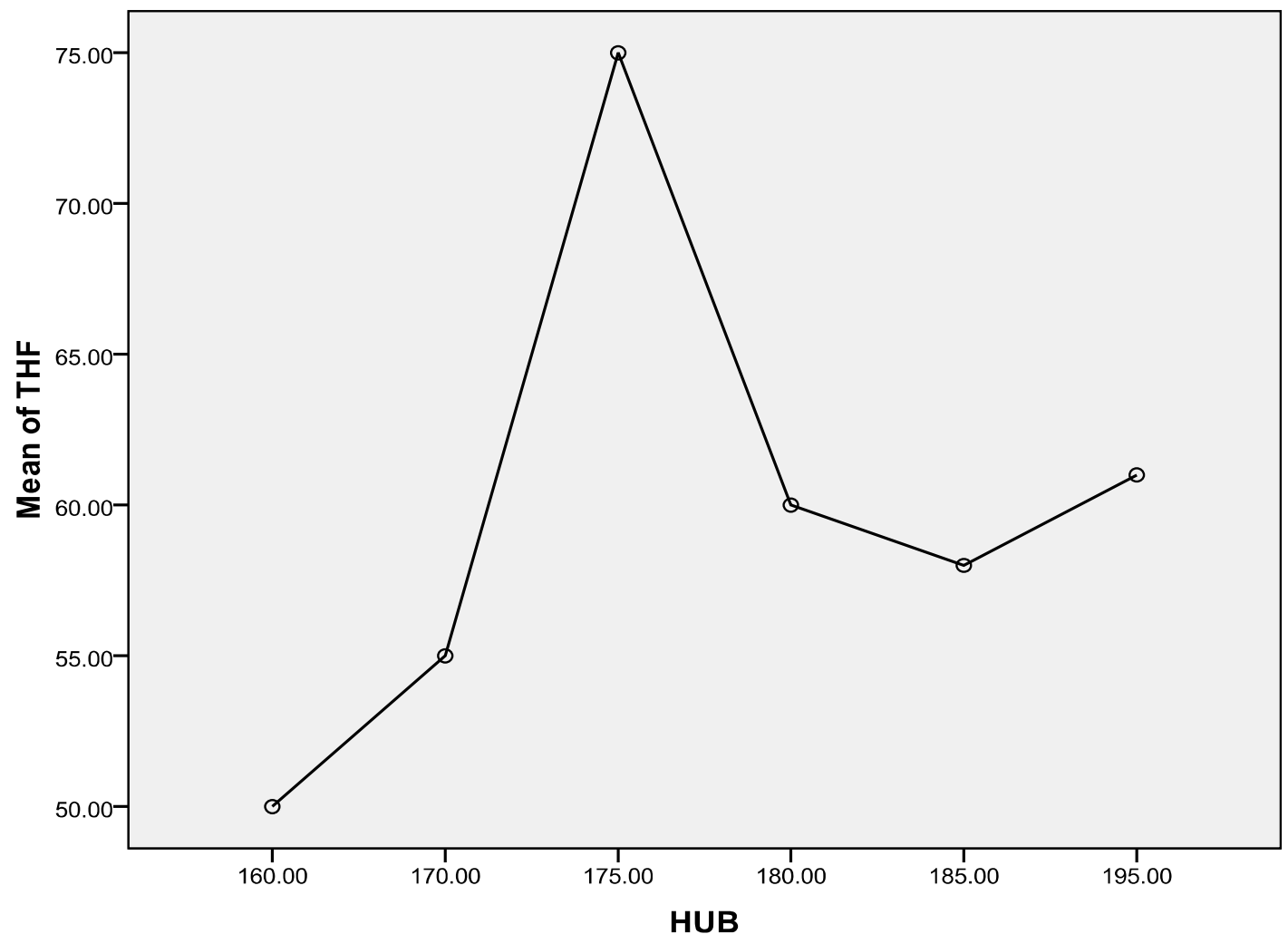

Figure $\mathbf{8 b}$. Structure detection between THF and HUB using means plot. 


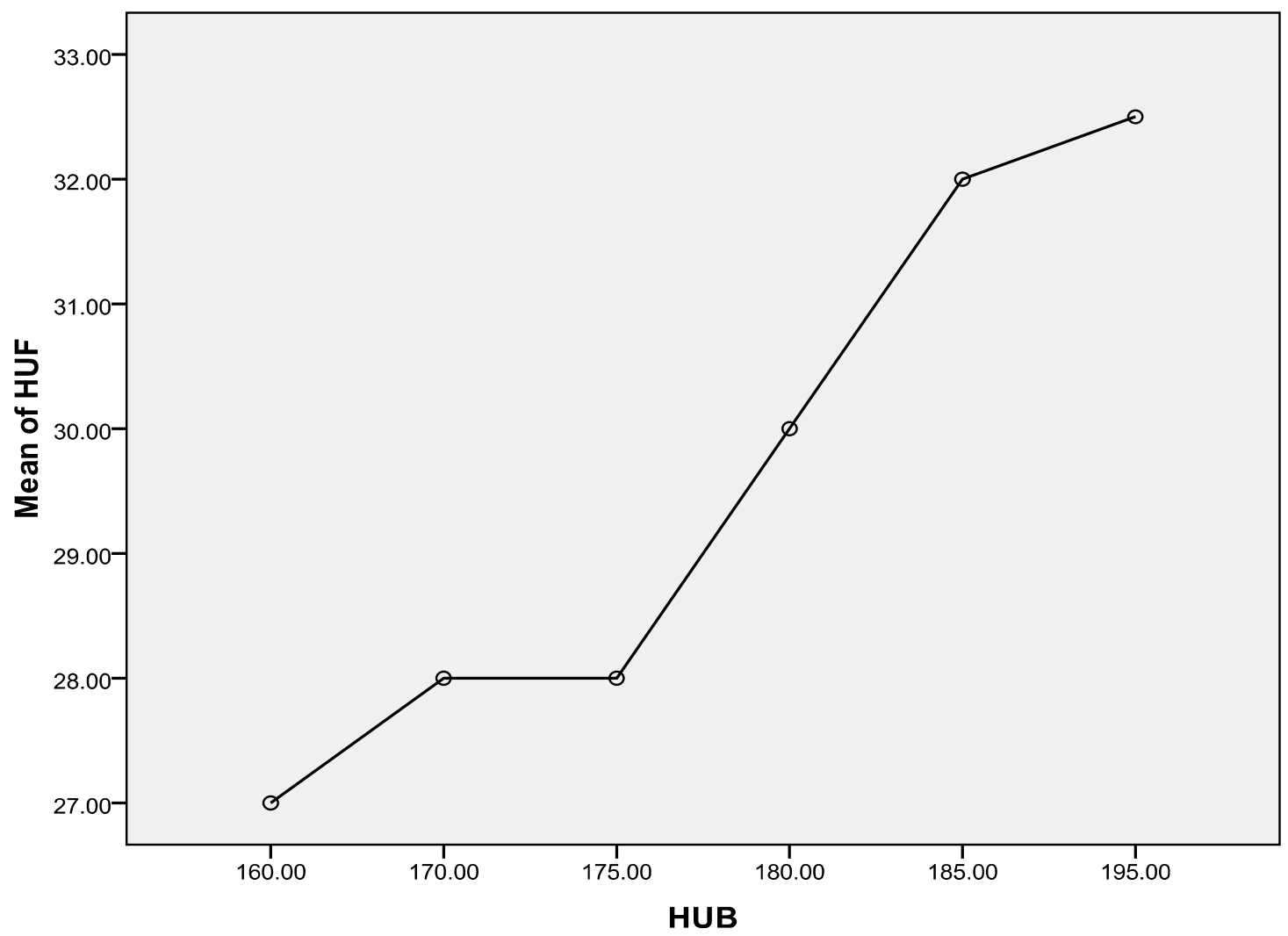

Figure 8c. Structure detection between HUF and HUB using means plot.

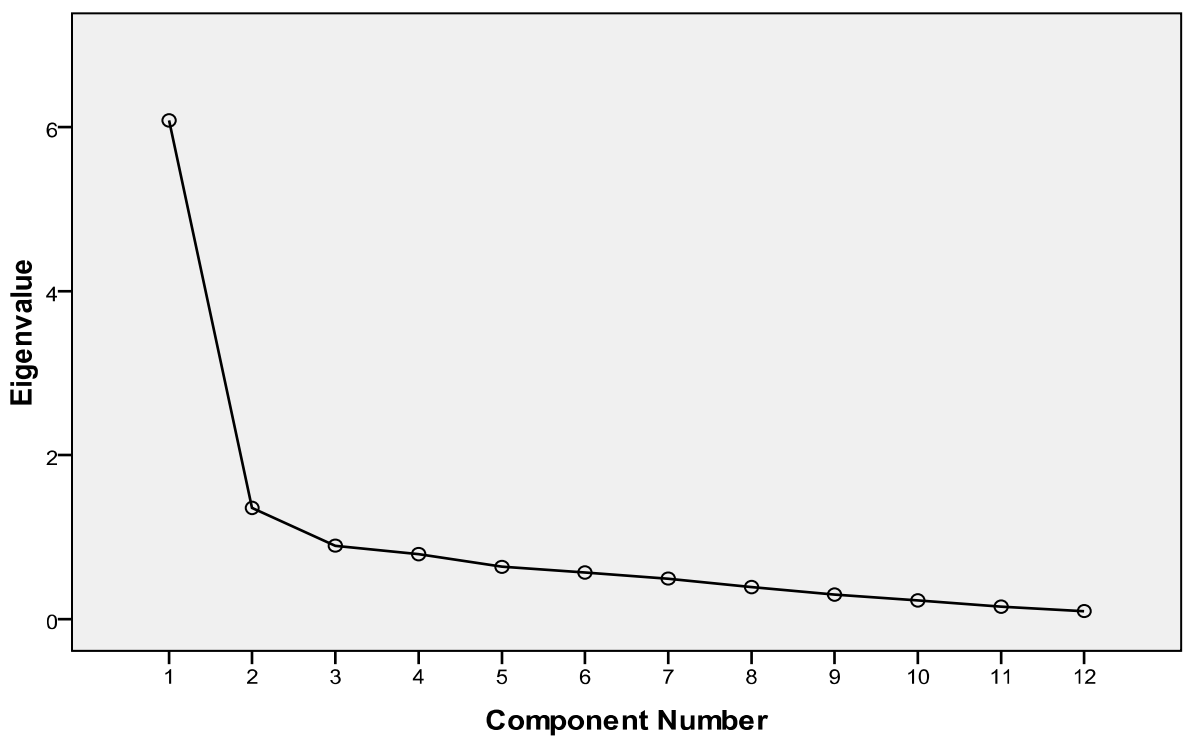

Figure 9. Scree plot of the eigenvalues of the principal components.

variables, leaving only $38 \%$ loss of information. Figure 9 shows the Scree plot of the eigenvalues of the PCs in the initial solution. None of the remaining PCs accounted for more than $8 \%$ of the variability and so, were excluded from the analysis. PC 1 alone explained nearly $51 \%$ of the variance, while PC 2 explained about $11 \%$ of the variance. The rotated component matrix showed that the first component (PC 1) was most highly correlated with 


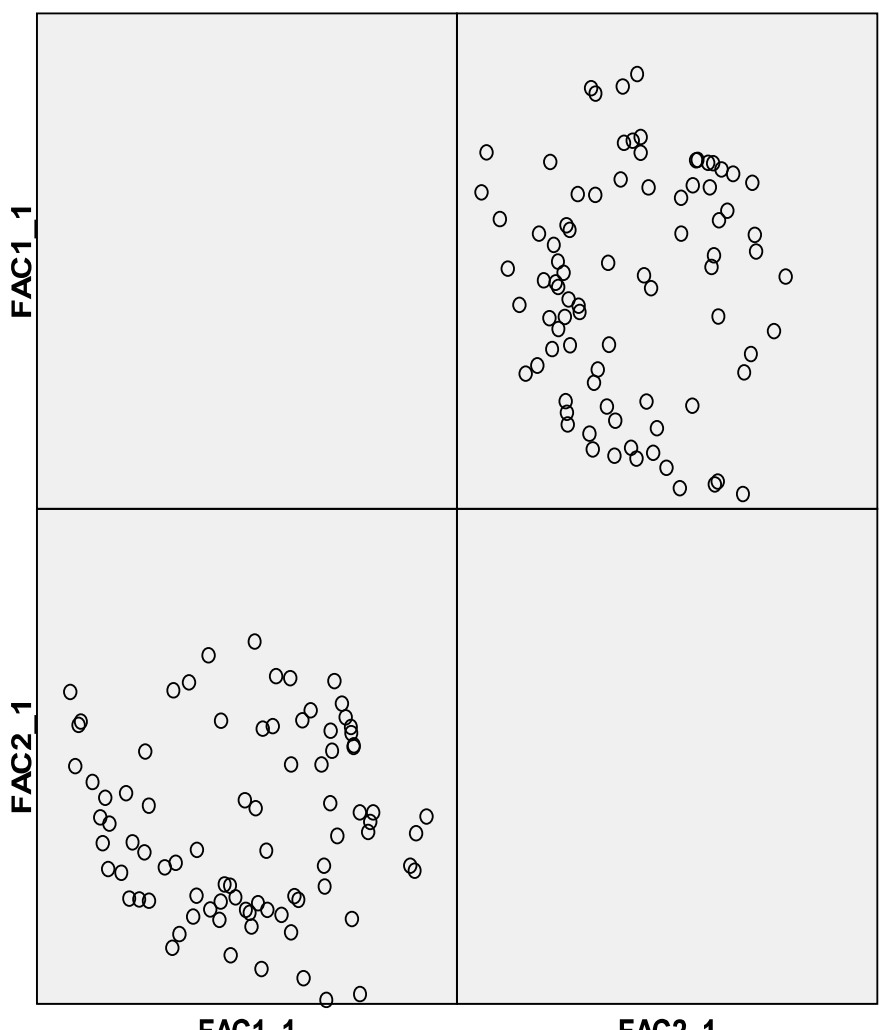

FAC1_1

FAC2_1

Figure 10. Scatterplot matrix of component scores.

sulphate, while the second (PC 2) was most correlated with nitrate concentrations. The scatterplot matrix of the component scores (Figure 10) revealed a fairly skewed distribution for the extracted factors.

\section{Abundance and diversity in plankton assemblages}

Two heterotrophic microbial groups (total heterotrophic bacteria-THB and total heterotrophic fungi-THF) and two hydrocarbonoclastic groups (hydrocarbon utilizing bacteria-HUB and hydrocarbon utilizing fungi-HUF) were enumerated. THB counts ranged between $1.50 \times 10^{2}$ and $2.80 \times 10^{2}\left(2.10 \times 10^{2} \pm 14.10\right) \mathrm{cfu} / \mathrm{ml}$, THF between 2.50 $\times 10^{1}$ and $7.50 \times 10^{1}\left(4.5 \times 10^{1} \pm 4.41\right) \mathrm{cfu} / \mathrm{ml}$, HUB between $8.50 \times 10^{1}$ and $1.95 \times 10^{2}\left(1.35 \times 10^{2} \pm 12.74\right)$ $\mathrm{cfu} / \mathrm{ml}$, and HUF between $2.00 \times 10^{1}$ and $3.5 \times 10^{1}(3.0 \times$ $\left.10^{1} \pm 1.16\right) \mathrm{cfu} / \mathrm{ml}$. The order of abundance of all the groups was $\mathrm{THB}>\mathrm{HUB}>\mathrm{THF}>\mathrm{HUF}$.

Through biochemical characterizations, 7 HUB genera (Bacillus sp., Arthrobacter sp., Corynebacter sp., Pseudomonas sp., E. coli, Micrococcus sp. and Serratia $\mathrm{sp}$.) and through cultural characterization and microscopic appearance, 4 HUF genera (Rhizopus sp., Cladosporium sp., Aspergillus sp. and Mucor sp.) were identified.

\section{Spatial variation in abundance of plankton groups}

Highest total microbial abundances $\left(9.02 \times 10^{2} \mathrm{cfu} / \mathrm{ml}\right)$ was recorded in sampling location 7 and least abundance of $7.47 \times 10^{2} \mathrm{cfu} / \mathrm{ml}$ was recorded in location 1 ; with fairly steady increases in counts of the THF and HUF from location 1 to 7 (Figure 11).

\section{Physicochemical variables and plankton abundance}

Few of the physicochemical variables exerted significant influences on the microbial groups. Conductivity correlated negatively with HUF $(r=-0.555)$ and THC with THB $(r=-0.635)$, THF $(r=-0.642)$ and HUB $(r=-0.596)$ at $P<0.05$. However at $P<0.01$, nitrate $(P C 2)$ correlated negatively with HUF $(r=-0.687)$.

\section{DISCUSSION}

The water temperature range of the present study falls within the value reported by Alabaster and Lloyd (1980) for natural inland water in the tropics, especially those in the Niger Delta region (NADECO, 1980; SPDC, 1998), and so did pH (Ombu, 1987; Hart, 1994; Yakubu et al., 1996; Mansi, 1997; Ikomah, 1999) and nitrate concentrations (Amadi et al., 1997; Edoghotu and Aleleye-Wokoma, 2007; Chindah, 1998), as well as sulphate and phosphate contents (Odokuma and Okpokwasili, 1992; Izonfuo and Bariweni, 2001). High turbidity recorded in the present study could result in the reduction of solar irradiation in the water column, thus leading to decreased productivity by the autotrophs, including phytoplankton and bacterioplankton (Adakole et al., 2003). Moore and Moore (1976) reported that THC concentration of less than $100 \mathrm{mg} / \mathrm{l}$ in the environment is considered to be of biogenic origin while excess may be due to anthropogenic inputs such as board engines and oil effluents of crude oil pollution. This thus places the source of the hydrocarbon contents of this river as not anthropogenic in origin. However, hydrocarbons were severally undetected at sampling location 1 (the upstream point), but mean values slightly increased downstream; a trend that best indicates the proximal inputs from the neighbouring oil and gas activities in locations 2-7. Oghenejoboh (2005) had also detected sizeable concentrations of petroleum hydrocarbons in the freshwaters of some communities of the Niger Delta region of Nigeria where there are active and prolonged gas flaring.

The microbial groups isolated in this study were similar to those reported from various Niger Delta aquatic systems (Chikere and Okpokwasili, 2001; 2002; 2004). The observed spatial variations in densities indicates some degree of micro habitats made possible by corresponding gradiential variation in physicochemical 


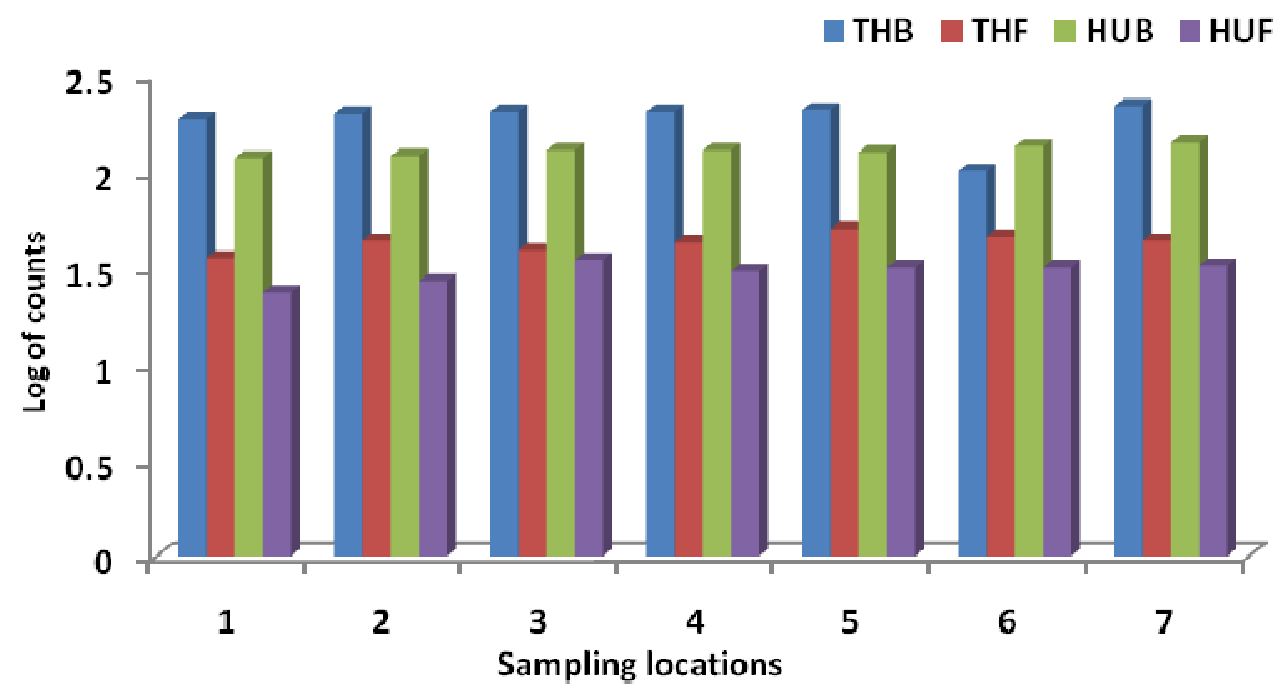

Figure 11. Spatial variation in bacterioplankton groups of Imo River in ELGA.

attributes such as conductivity, nitrate and petroleum hydrocarbon concentrations. Coincidentally, sampling location 7, which recorded the highest microbial counts, and location 1, with the least count also recorded the highest and least THC concentrations, respectively. Other than with the HUB and HUF, the highest counts also recorded for the THB and THF in location 7 confirm the observations of Bossert and Bartha (1984) that hydrocarbons end not only to enrich the hydrocarbon utilizers, but also for additional populations that utilize the bye-products that are not intact hydrocarbons. Additionally, the maximum value recorded for temperature, another limiting factor in aquatic ecosystems in sampling location 7 must have contributed to high densities of the microbial planktonic groups (lbelings et al., 2010). On the other hand, minimum values of the nutrient, nitrate, another limiting factor in sampling location 1 may have contributed to the observed least microbial densities (Spaak and Bauchrowitz, 2010).

The observed significant influences of conductivity and nitrate on planktonic group counts indicate the requirement of certain ions (Moss, 1993; Adakole et al., 2003) and nutrients (UNEP GEMS, 2006), respectively for microbial growths. The contributory correlational effects of THC on the planktonic groups confirm its significant role in bacteria and fungi abundance and diversity in hydrocarbon-rich habitats.

The PC analysis highlighted two major trends among the physicochemical variables. The first component, sulphate, and the second, nitrate have been identified as nutrients that affect planktonic community abundance (Wright et al., 1993; Ayodele and Adeniyi, 2006; Spaak and Bauchrowitz, 2010). The high negative correlation of PC 2 with HUF suggests that nitrate varied systematically with the mycoplankton assemblage.

\section{Summary}

The present study revealed gradientially varying physicochemical and microbial attributes of the Imo River in a Niger Delta region of Nigeria. Bacterio- and mycoplankton assemblages were most abundant in sampling location 7 and least abundant in location 1; and so were mean surface water temperature and total petroleum hydrocarbon (THC) concentrations highest in sampling location 7 and THC and nitrate concentrations least in location 1. There were observed significant spatial inequalities in both physicochemical variables and microbial assemblages.

The PC analysis revealed two major componentssulphate and nitrate, forming the extraction solution and explaining nearly $62 \%$ of the variability in the original 12 variables. None of the remaining PCs accounted for more than $8 \%$ of the variability. PC 1 alone explained nearly $51 \%$ of the variance, while PC 2 explained about $11 \%$ of the variance. PC 2 correlated ( $r$ ) negatively with HUF at $P<0.01$, even as conductivity correlated negatively with HUF, and THC with THB, THF and HUB at $\mathrm{P}<0.05$.

Biochemical characterizations revealed 7 HUB genera (Bacillus sp., Arthrobacter sp., Corynebacter sp., Pseudomonas sp., E. coli, Micrococcus sp. and Serratia sp.) while cultural characterization and microscopic appearance revealed 4 HUF genera (Rhizopus sp., Cladosporium sp., Aspergillus sp. and Mucor sp.) across the sampling locations.

\section{REFERENCES}

Aas P, Lyons M, Pledger R, Mitchell DL, Jeffrey WH (1996). Inhibition of bacterial activities by solar radiation in nearshore waters and the Gulf of Mexico. Aquatic Microbial Ecol., 11: 229-238.

Adakole JA, Mbah CE, Dalla MA (2003). Physicochemical Limnology of 
Lake Kubanni, Zaria- Nigeria. $29^{\text {th }}$ WEDC International Conference "Towards the Millenium Development Goals", Abuja, Nigeria.

Alabaster JS, Lloyd R (1980). Water Quality Criteria for Freshwater fish. London: Butterworths, p. 299.

Amadi N, Chindah AC, Ugoji CC (1997). The effect of municipal drainage on the microflora of a Black Water stream in Port Harcourt, Nigeria. Niger Delta Biologia, 2(1): 125-139.

Aoyagui ASM, Bonecker CC (2004). Rotifers in different environments of the Upper Parana River floodplain (Brazil): richness, abundance and the relationship of conductivity. Hydrobiologia, 522: 281-290.

APHA (American Public Health Association) (1998). Standard Methods for the Examination of Water and Wastewater. $20^{\text {th }}$ ed. APHA/AWWA/WEF: Washington DC.

Armitage PD, Blackburn JH (1985). Chironomidae in a Pennine stream system receiving mine drainage and organic enrichment. Hydrobiologia, 121: 165-172.

Ayodele HA, Adeniyi IF (2006). The zooplankton fauna of six impoundments on River Osun, Southwest Nigeria. The Zoologist, 1(4): 49-67.

Bergey DB, Holt JG (1993). Bergey's Manual of Determinative Bacteriology. Noel R. Krieg et al., eds. Williams and Wilkings Publishers, p. 816

Bossert I, Bartha R (1984). The fate of petroleum in soil ecosystem. Petroleum Microbiology. Macmillan Publishers Co., New York, pp. 436-473.

Boyd PW (2000). A Mesoscale phytoplankton bloom in the polar southern Ocean stimulated by iron fertilization. Nature, 407: 695-702.

Cairns Jr J, van der Schalie WH (1980). Biological Monitoring 1: Early warning systems. Water Res., 14: 1179-1196.

Chikere BO, Okpokwasili GC (2001). Organic pollution in a Niger Delta river receiving petrochemical effluents. Trop. Freshwater Biol., 10: 19-33.

Chikere BO, Okpokwasili GC (2002). Seasonal dynamics of the organic pollution in a Niger Delta river receiving petrochemical effluents. Trop. Freshwater Biol., 11: 11-22.

Chikere BO, Okpokwasili GC (2004). Frequent occurrence of microorganisms at a petroleum effluent outfall site. J. Trop. Bioscience, 4: 12-18.

Chindah AC (1998). The spatial and temporal variations in the epipelic algal community of Bonny/New Calabar Estuary of the Niger Delta. Ph.D. Thesis. Department of Biological Sciences, Rivers State University of Science and Technology, Port Harcourt., 19: 214.

Edoghotu AJ, Aleleye-Wokoma IP (2007). Seasonal variations in phytoplankton composition and physicochemical properties of Ntawoba Creek, Port Harcourt, Nigeria. Inter. J. Nat. Appl. Sci., 3(3): 344-348.

Egborge ABM (1994). Water Pollution in Nigeria Vol. 1: Biodiversity and Chemistry of Warri River. Ben Miller Books Nig. Ltd., p. 313.

Garcia-Pichel F (1994). A model for the internal self-shading in planktonic organisms and its implications for the usefulness of ultraviolet sunscreens. Limnol. Oceanogra., 39: 1704-1717.

Hart Al (1994). The ecology of the communities of benthic macrofauna in the mangrove swamp of Port Harcourt area of the Niger Delta. Ph.D. Thesis, University of Port Harcourt, Rivers State, Nigeria, 17: 286.

Havas M, Hutchinson TC (1982). Aquatic Invertebrates from the Smoking Hills, NWT: Effect of $\mathrm{pH}$ and Metals on Mortality. Can. J. Fisheries Aquatic Sci., 39: 890-903.

Ikomah FB (1999). The impact of fertilizer plant effluent on ecology of the littoral benthos of Okrika (NAFCON) Creek. M.Sc. Thesis, Rivers State University of Science and Technology, Port Harcourt, Nigeria., 12: 154.

Izonfuo LWA, Bariweni AP (2001). The effect of urban runoff water and human activities on some physico-chemical parameters of the Epie Creek in the Niger Delta. Appl. Sci. Environ. Manage., 5(1): 47-55.
Karentz D, Bothwell ML, Coffin RB, Hanson A, Herndl GJ, Kilham SS, Lesser MP, Lindell M, Moeller RE, Morris DP, Neale PJ, Sanders RW, Weiler CS, Wetzel RG (1994). Report of working group on bacteria and phytoplankton. In: Impact of UV-B Radiation on pelagic freshwater ecosystems. Archiv fur Hydrobiologie Beiheft 43 (Special Issue). Williamson, C.E. and Zagarese, H.E. eds., pp. 31-69.

Mansi SE (1997). An ecological survey of the benthic macroinvertebrate communities after dredging activities in an intertidal mangrove swamp of the Niger Delta. M.Sc. Thesis, University of Port Harcourt, 12: 128.

Mills A, Lu CB, Cowell RR (1978). Enumeration of petroleum degrading marine and estuarine microorganisms by the most probable number method. Can. J. Microbiol., 24: 552-557.

Moore WJ, Moore EA (1976). Environmental Chemistry. London: Academic Press Inc.

Moss B (1993). Ecology of Freshwaters- man and medium, $2^{\text {nd }}$ ed. London: Blackwell Scientific Publication, p. 417.

NADECO (1980). The Waters of the Niger Delta. Reports of an investigation by the Netherlands Engineering Consultants. The Hague., pp. 210-228.

Newell GE, Newell RC (1963). Marine Plankton: A Practical Guide. London: Hutchinson Educational Ltd., p. 207.

Odokuma LO, Okpokwasili GC (1992). Role of composition in degradation of oil spill dispersants. Waste Manage., 17: 491-496.

Oghenejoboh KM (2005). The impact of acid rain deposition resulting from natural gas flaring on the socioeconomic life of the people of Afiesere Community in Nigeria's Niger Delta. J. Ind. Pollution Control, 21(1): 83-90.

Okogwu OI, Ugwumba OA (2006). The zooplankton and environmental characteristics of Ologe Lagoon, South West Nigeria. The Zoologist, 1(4): 86-92.

Okpokwasili GC, Amanchukwu SC (1988). Petroleum hydrocarbon degradation by Candida species. Environ. Inter., 14: 243-247.

Ombu EJ (1987). The impact of Okrika oil terminal on the littoral benthos of the Central Bonny Estuary, Nigeria. M.Phil. Thesis, Rivers State University of Science and Technology, Port Harcourt.

Pomeroy LR, Wiebe WJ (1988). Energetics of microbial food webs. Hydrobilogia, 159: 7-18.

Shell Petroleum Development Company of Nigeria Limited (SPDC) (1998). Environmental Impact Assessment of Obigbo Node Associated Gas Gathering Project: Final Report by Tial Trade Limited.

Spaak P, Bauchrowitz M (2010). Environmental influences and plankton dynamics. Eawag News: Swiss Federal Institute of Aquatic Science and Technology, 69e: 25-27.

Thijsse GJE, van der Linden AC (1961). Iso-alkane oxidation by a Pseudomonas. Antonie van Leeuwenhoex J. Microbiol., 27: 171-179.

United Nations Environmental Programme Global Environment Monitoring System (UNEP GEMS)/Water Programme. (2006). Water quality for ecosystem and human health.

Wright JF, Furse MT, Armitage PD (1993). RIVPACS, a technique for evaluating the biological quality of rivers in the UK. European Water Pollution Control, 3: 15-25.

Yakubu AF, Adeyemo AA, Ayina DA (1996). Effect of deforestation on the abundance and distribution of crab in the Eagle Island mangrove swamp of the Niger Delta. NIOMR Technical Paper, 103: 7-9.

Yamamoto M (1986) Study of the Japanese Chironomus inhabiting high acid water (diptera, chironomidae) 1. Kontyu, 54: 324-332. 